\title{
Intervening in and Preventing Somali-American Radicalization with Counter Narratives: Testing the Breaking the ISIS Brand Counter Narrative Videos in American Somali Focus Group Settings
}

Anne Speckhard International Center for the Study of Violent Extremism, annespeckhard@icsve.org

Ardian Shajkovci

International Center for the Study of Violent Extremism, ardianshajkovci@americanactri.org

Mohamed Ahmed

International Center for the Study of Violent Extremism, mohamedahmed@icsve.org

Follow this and additional works at: https://digitalcommons.usf.edu/jss

pp. 32-71

\section{Recommended Citation}

Speckhard, Anne; Shajkovci, Ardian; and Ahmed, Mohamed. "Intervening in and Preventing Somali-American Radicalization with Counter Narratives: Testing the Breaking the ISIS Brand Counter Narrative Videos in American Somali Focus Group Settings." Journal of Strategic Security 11, no. 4 (2019) : 32-71.

DOI: https://doi.org/10.5038/1944-0472.11.4.1695

Available at: https://digitalcommons.usf.edu/jss/vol11/iss4/3

This Article is brought to you for free and open access by the Open Access Journals at Digital Commons @ University of South Florida. It has been accepted for inclusion in Journal of Strategic Security by an authorized editor of Digital Commons @ University of South Florida. For more information, please contact digitalcommons@usf.edu. 


\title{
Intervening in and Preventing Somali-American Radicalization with Counter Narratives: Testing the Breaking the ISIS Brand Counter Narrative Videos in American Somali Focus Group Settings
}

\begin{abstract}
Research focused on measuring attitudes towards violent extremist groups and the appeal of violent extremist ideologies among the vulnerable communities in the United States remains under-researched. This focus group research attempts to close such a research gap. In May of 2018, International Center for the Study of Violent Extremism (ICSVE) researchers focus tested ICSVE-produced counter-narratives with Somali-American youth in San Diego, CA, namely with Somali-American youth convened at the East African Cultural Community Center and the premises of San Diego State University. In addition to raising awareness about the dangers of joining violent extremist groups like Islamic State of Iraq and the Levant (ISIS) and lending promising evidence that speaks to the quality and authenticity of our counter-narratives, this article presents a methodological argument, or a case study, in the use of counter narratives as an effective Counter Violent Extremism (CVE) tool. The use of counter narratives also served to start important conversations and engage with the Somali American community in a way that could open a path towards testing our counter-narrative content among those whom we might be able to detect a more substantial persuasive effect.
\end{abstract}

\section{Acknowledgements}

The International Center for the Study of Violent Extremism thanks the Embassy of Qatar in Washington, D.C. and Facebook for their partial support to the Breaking the ISIS Brand Counter Narrative Project. 


\section{Introduction}

As many as 40,000 foreign fighters from more than 110 countries joined ISIS and other jihadist groups in Iraq and Syria. ${ }^{1}$ In the United States alone, over 200 individuals were either recruited or groomed into joining ISIS in Syria and Iraq. ${ }^{2}$ The George Washington University's (GWU) Program on Extremism researchers listed Ohio, Virginia, and Minnesota as the states with highest volunteer rate into conflict zones in Iraq and Syria. 3 These are states with a high representation, vis a vis other states, of Somali immigrants. ISIS and other violent extremist groups have been particularly successful in targeting Somali-American communities, which are primarily concentrated in Columbus, Ohio; San Diego, California; and St Paul, Minnesota, with a considerable presence in the Commonwealth of Virginia as well.4

As of 2016, at least 20 young Minnesotans, primarily ethnic Somalis, have left to join violent extremist groups in Iraq and Syria, with at least five believed to have been killed there.5 At least nine Minnesotans have been arrested since 2014 for attempting to join terrorist groups in Iraq and Syria. ${ }^{6}$ Other examples include twenty-nine-year-old Abdifatah Dayib Ahmed, also known as Abdirahman Muhumed, who left Minnesota in 2014 to join ISIS in Syria. He was reportedly killed in Syria. 7 Likewise, Somali American Mohamed Osman Mahmoud was sentenced to 30 years in prison in 2014 for his alleged role in planning to detonate a bomb at a tree-lighting ceremony in Portland, Oregon. ${ }^{8}$

As the evidence suggests, Somali Americans in particular remain vulnerable for recruitment into ISIS and other violent extremist groups. Communities at risk, such as Somali, and those serving them, need the necessary training and tools to counter the narratives and calls to action of violent extremist groups like ISIS. Such groups are currently active on social media, and even pinpoint these communities. 9

While ISIS is likely to lose its remaining strongholds in Syria, as it has in much of Iraq, its powerful ideology, operations, and tactics are likely to remain active. In fact, there is strong evidence to suggest that the terrorist group has not disappeared despite its territorial loses and heavy decapitation of the leadership. ${ }^{10}$ The group has morphed into an underground insurgency and movement heavily networked through the now global dispersion of its fighter supporters. ${ }^{11}$ It remains capable of maintaining and further strengthening its remaining networks; deploying battle-hardened terrorists to wage terrorist acts in the country of origin or elsewhere; and to lure in, inspire, and encourage those who never managed to travel to Syria or Iraq to attack at home.

In addition to defeating them militarily on the ground, central to our CVE efforts remains the task of preventing attacks at home by raising 
awareness about the dangers emanating from violent extremist groups and building resilience to recruitment in our communities. Civil society organizations have a major role to play in this respect, especially when knowing that many vulnerable Muslim communities in the United States remain skeptical of government involvement in CVE-related matters-and at times of CVE initiatives at all-often suspecting anyone involved in CVE matters as working as government informants. ${ }^{12}$

This article reports on the ICSVE's efforts to offer access to such resources to Somali community members in San Diego, CA. ICSVE organized community sponsored activist meetings held in small groups with Somali American youth at the East African Cultural Community Center and the premises of San Diego State University. ${ }^{13}$ The goal was to engage them in discussions about the ICSVE Breaking the ISIS Brand Counter Narrative videos, which feature ISIS defectors, returnees, and prisoners speaking out against the group. The authors used two methods to conduct their study: Focus groups for data collection and content analysis for data analysis.

\section{Somali-American Radicalization and Violent Extremism Context}

While all communities remain susceptible and vulnerable to the appeal of terrorist organizations like ISIS and al Shabaab, the appeal and susceptibility of the Somali-American community to such groups remains especially puzzling for many CVE and government professionals. Several factors, namely a complex set of grievances, whether real or perceived, rooted in negative perceptions towards Muslims in general and black males in particular are key contributors. Other factors include a profound identity crisis among the American-Somali youth rooted in being new immigrants and often entering an unsupportive, if not hostile, environment along with challenged family structures with the loss of father figures for many new immigrants who fled from war-torn Somalia. Socially, a milieu remains highly concerned over ongoing civil conflict in Somalia, and social and educational systems often fail to provide adequate safety nets. Local imams also fail at times to understand, reach, and educate Somali American youth about positive and peaceful interpretations of Islam that might explain the struggle of the SomaliAmerican community to effectively counter the appeal of violent extremists and terrorist groups. All of these factors have presented an opportunity for extremist groups to manipulate these communities and encourage vulnerable youth living in America to join terrorist groups such as al-Shabaab and ISIS. ${ }^{14}$

Research has highlighted identity-related challenges within the SomaliAmerican community, as many of them belong to the pool of firstgeneration immigrants and have in many cases failed to integrate into mainstream society. Vulnerabilities also become apparent as many 
Somalis occupy shares of single-family households that have been traumatically bereaved and lacking a father figure. ${ }^{15}$ In combination, all these factors appear to increase the lure of groups like ISIS and al Shabaab, who seem to offer them a fictive kinship, masculine role models, and escape from boredom and frustration. They also offer adventures, alongside new positive identities and feelings of personal significance to address global conflicts and seek meaning and purpose in life.

The combined issues of individual and collective history of psychological traumatization, community tensions upon landing in the United States, customary immigrant-related challenges, and family bereavements and broken families all play a part. These could also be categorized as issues of identity, challenged family structures, educational and social mobility challenges, grievances over discrimination (perceived and real), and so forth. All these conditions make them vulnerable to violent extremist groups like ISIS.

Some authors find poverty and lack of social mobility as questionable motivations for departing to the conflict zones in Iraq and Syria. ${ }^{16}$ Indeed, poverty and lack of social mobility alone are unlikely to be sufficient causes for joining, but these factors become important when combined with exposure to a terrorist group and its ideology. Terrorist groups tend to take advantage of these factors, but without exposure to the group, we are highly unlikely to a see a terrorist emerge or form. Others also stress the lack of adequate "language and cultural training prior to migration [primarily following the ousting of general Mohamed Siad Barre in 1991] as a reason leading to the greater insularity of Somali community compared to other, more integrated Muslim immigrant communities," which may also be another factor challenging these particular immigrants. ${ }^{17}$

At the ICSVE, we generally view the making of a terrorist as a function of multiple levels of actors and forces. To make a terrorist, there must be a group purporting to represent some segment of a society and presenting violence as an answer to contentious socio-political issues facing that particular segment of the society. The group also provides an ideology to justify terrorist violence and garner social support for both the group and its ideology. Three variables - the group, ideology, and social supportthen interact with the vulnerabilities and motivations existing at the level of the individual. 18

In the case of Somali-American recruitment, the legacy of the conflict in Somalia and the active presence of terrorist groups there have created enduring opportunities and links for Somali-American immigrants to join "jihad" back in Somalia. This was first evidenced through a first wave of young Somalis departing Minneapolis and other areas to support alShabaab and other groups in Somalia between 2006 and 2011. This wave 
speaks to the success of groups like al-Shabaab, and later ISIS, at recruiting among the members of Somali-American community. ${ }^{19}$ In Minnesota, a European al Shabaab fighter became the first to recruit among vulnerable Somali youth. He stressed the urgency to join the conflict in defense of what he claimed would be the massive rape of their Somali "sisters" by foreign Kenyan soldiers. ${ }^{20}$ This narrative naturally appealed to the challenged manhood of young immigrant Somali men who were finding they were failing to integrate into Somali American community or who at times even felt rejected by the African-American community. ${ }^{21}$

The first wave of Somali Americans became their own force of recruitment, namely using Twitter, Facebook and other social media platforms to induce, incite, and shame their fellow Somali Americans into joining. This led to the creation of the second wave of Minnesotan Somali American recruits. Although in many cases socially better integrated-even included an aspiring medical student among them-they responded to the appeal of their "brothers" who used social media to glorify the Somali "jihad" while often shaming their counterparts for "hanging out at the Mall of America." 22

Later waves of Somali-American immigrants joining and attempting to join terrorist groups abroad followed the onset of the Syrian conflicts and the partial merging of ISIS and al Shabaab. ${ }^{23}$ During this time, Somalis were recruited not only into al Shabaab but also into ISIS in Iraq and Syria. While on-the-ground recruitment and grooming for recruitment during all three waves of recruitment of Somali Americans appears to have been minimal, with nearly all coming via the Internet, some suggest that recruiters sending young Somalis to the conflict zones in Iraq and Syria were the same recruiters who sent many young Somalis to join Al Shabaab and other groups in Somalia. ${ }^{24}$

Whereas on-the-ground ISIS recruiters and networks facilitating travel to Syria and Iraq were quite active in Europe and the Balkans, in the United, for instance, the most recruiting has occurred via the Internet. Sometimes, the process involved one or more individuals serving as a recruitment node using downloads and online connections to facilitate further face-toface recruiting with others on- the- ground inside the United States. Although social media and online recruitment is known to play an important role in moving individuals inside the United States along the violent extremism and terrorism trajectory, with respect to the members of Somali community in the Minneapolis-St. Paul area, some suggest that face-to-face interactions represented the key component of recruitment into terrorist organizations like ISIS. In other words, social media and online recruitment in the context of Somali community recruitment in the Minneapolis-St. Paul area primarily served to spread extremist messages already propagated by extremist recruiters on the ground. ${ }^{25}$ While 
evidence exists to suggest that some youth who downloaded extremist propaganda served as recruitment hubs for inciting others, evidence of actual recruiters traveling in from outside the United States to target these communities when it came to ISIS remains largely absent.

Whereas al-Shabaab recruiters appealed to an "Islamic-nationalist identity" to lure its potential recruits-also as a means to overcome clan divisions within the country-though recently it has also resorted to the call for "Islamist nationalism" to mobilize, ISIS recruitment widened to those of other victims of war-torn areas and to the idea of global jihad and the so-called Caliphate it created. ${ }^{26}$ Some argued that while ISIS' appeal served to antagonize local jihadi groups (for example, in Somalia) and other powerful non-Muslim states in the region, the group deemed such a strategy as necessary to both attract recruits in the so-called Caliphate and reclaim the status of the "champion of the global jihadist ideal." ${ }^{27}$ In addressing this change in recruitment appeals between al Shabaab and ISIS, as well as the phenomenon of young Twin City Somali travelers the conflict zone in Syria, some researchers note:

Al Shabaab's recruiting message had been based on nationalism and genealogy, as well as religion, and multiple sources said they could understand the enduring desire to see their mother country stabilize and improve, even as they disagreed with the extremist interpretation of Islam that al Shabaab espouses. In Syria, however, that nationalistic zeal does not apply, meaning recruiters are attracting young people not based on their country of origin but by appealing to the notion of a global Muslim community and ISIL's vision of a caliphate and apocalypse. ${ }^{28}$

Policy recommendations stemming from studies focused on the SomaliAmerican community included helping immigrants to integrate by extending more resources to the community and helping them to overcome obstacles to integrating successfully. The recommendations highlighted that the "self-imposed" segregation and a desire to adhere to cultural heritage in the Somali American community may also serve as a leeway for radical extremist elements to radicalize young Somalis even more, and that some changes may need to occur from inside the community as well. They also included winning "the hearts and minds" of the community so as not to alienate crucial partners in the fight against violent extremism. ${ }^{29}$ Indeed, in some Somali American communities, the words CVE and counter-terrorism seem to have taken on a negative connotation and are being associated with informants and negative profiling. ${ }^{30}$

Other studies on the Somali-American community identified both challenges related to extremism and measures aimed at reducing susceptibility to radicalization and recruitment. One such measure 
included a focus on "multi-level community" interventions. The value of approaching the issue of extremism from this perspective is that it extends beyond family-level interventions and takes a systemic view of the problems. Such projects have also been defined as long-term, social, economic, and educational in nature. For instance, multi-level intervention programs are called for to engage local imams and other important community leaders in the ideological debate and provide them with necessary tools and training to prevent the recruitment of Somali youth. These reputable imams and religious workers, or other Somali male mentors, would also be enlisted to work with youth and encourage their development in the areas of education, careers, and personal development. Others recommended generating programs that encourage civil engagement and public service among the young. An equally important aspect of the multi-level intervention approach is to counter extremist narratives and propaganda online by introducing alternative viewpoints targeted through public messaging and information campaigns. ${ }^{1}$

Community-level collaborative partnerships are highlighted in the literature as being important in developing, testing, and monitoring intervention prevention strategies through partnerships with local associates, businesses, and mosques - to just name a few. The emphasis is placed on interdisciplinary collaborations involving law enforcement, education, social and mental health services, and academia. The primary goal of such interventions is to identify relevant psychosocial and societal processes from within the Somali-American community that could potentially strengthen counter radicalization and counterterrorism efforts. The specific program initiatives include leveraging psychosocial processes, namely understand the inter-relatedness between different social factors and an individual's thought, behavior, learning process, and other psychological factors, to support the activities of law enforcement in the realm of counterterrorism; generate collaborative radicalization prevention programs involving government, civil society, and other CVE practitioners and actors; generate research to better understand counterterrorism and/or psychosocial issues in these communities; and provide necessary culturally-based and culturally-informed education, training, and technical assistance to law enforcement and psychosocial workers fighting terrorism. ${ }^{2}$ In an effort to increase diversity within the force, some law enforcement units in the country have also begun to hire qualified candidates from within the Somali American community and allocate resources to community engagement efforts. 33

One such approach also involves strengthening community and family protective services. This can be done by encouraging and strengthening parental involvement in the areas such as education and mentoring. This is especially important given the history of violent conflicts many Somali families had to endure back in Somalia and the likelihood that many might carry scars of psychological trauma. This particular approach also involves 
government outreach activities and involvement of faith-based communities and organizations. Other efforts are focused on building family interventions through research and understanding of social circumstances from the perspective of refugees and the immigrant segment of Somali-American youth, including from single mother households. For instance, research into single mother Somali-American households may help to understand the challenges of mother-led families who are trying to cope with their youth. This could also help to understand how being from mother-led family households affects identify formation and how it may leave some vulnerable to looking for positive masculine relationships and models. 34

\section{Literature Review on Narratives and Counter-Narratives}

Corman defined narratives as a "system of stories that share themes, forms, and architypes." 35 Whereas stories represent a "sequence of events involving actors and actions," narratives do not require full stories, as they can simply be communicated through use of words, graphics, or phrases. ${ }^{6}$ The most effective narratives are the ones characterized by legitimacy, compelling purpose, consistency, quantifiable results, and relevancy in the eyes of potential supporters and sympathizers. 37

In designing narratives, extremist groups make use of historical events, religious terminology, political events, and appeal to higher authorities, among others, to generate an intended audience. $3^{8}$ Their narratives are strategically designed and customized to the needs and vulnerabilities of their target audience. They are also launched to motivate to engage and execute certain actions, including violent actions. 39 There is significant consensus regarding the impact of narratives on "beliefs, attitudes, intentions, and behaviors," both for the purposes of radicalization and to fight radicalization. $4^{\circ}$ Strictly speaking, in the context of violent extremism and terrorism, researchers have identified four criteria that are important in constructing counter-narratives:

1) "Revealing incongruities and contradictions in the terrorist narratives and how terrorists act,

2) Disrupting analogies between the target narrative and real-world events,

3) Disrupting binary themes of the group's ideology, and

4) Advocating an alternative view of the terrorist narrative's target." 41

Counter-narratives are especially powerful when 1) rooted in sound research and understanding of the extremist narrative, 2) rooted in the sound understanding of elements of radicalization and behavioral change, 3) aimed at specific [target] audience, 4) perceived by receiving audience as credible, and 5) format and message distribution is highly controlled. ${ }^{42}$ 
There are three types of messaging, narrative frameworks, or narrative approaches that can be effectively used to counter violent extremism: Alternative narratives, counter-narratives, and government strategic communications. 43 Counter-narratives serve to target and discredit terrorist groups and their ideologies by deconstructing and demystifying their messages to demonstrate their lies, hypocrisy, and inconsistencies. Briggs and Feve described counter-narratives as a strategy that "challenges extremist and violent extremist messages, whether directly or indirectly, through a range of online and offline means." 44 Provided they are logically structured and conceivable in the eyes of the target audience, they can be powerful in challenging and amplifying contradictions in extremist narrative. 45 While counter-narratives are reactive in nature, meaning they are created in response to certain extremist narratives, alternative narratives complement counter-narratives by emphasizing democratic values, positive social change, and "undercutting violent extremist narratives by focusing on what we are 'for' rather than 'against." 46

Lastly, government strategic communications refer to government efforts aimed at clarifying government policies, stance, or actions towards an issue. It also includes public awareness activities. Both government strategic communications and alternative narratives can be useful for prevention but are unlikely to reach those already being seduced by terrorist ideologies and groups and thereby narrowing their focus to messaging only from terrorists. In addition, both counter-narratives and alternative narratives can reinforce each-other's effectiveness if used simultaneously. 47

Both counter-narratives and alternative narratives are rooted in theoretical assumptions that they can be used to prevent and counter radicalization and violent extremism. Some authors question the utility of counter-narratives as a constructive method of preventing and countering violent extremism, as they are primarily focused on targeting ideology and that they fail to differentiate between violent behaviors and radical beliefs and ideology. 48 More specifically, some authors argued that there is a fallacy in assuming that ideas are root causes of violent behavior and that "violent acts can be prevented by removing or falsifying ideas." 49 Glazzard summarized such assumptions as "violent ideas lead to violent deeds, that counter-narratives can replace terrorist narratives, and that the actual threat of violent extremism can be mitigated through discourse."5o

Others contended that counter-narratives can be especially problematic in that they can strengthen extremists' conviction and further reinforce the narrative [for example, ideological] they are attempting to counter: " When counter-narrative talks up the ideology and demonizes it, the ideology is also glamorized and made more attractive, and it is empowered. ${ }^{51}$ Indeed, one should not discount potential impact when ideologically attenuated individuals view counter-narratives (cognitive 
dissonance) as well as the potential impact on those who are unsure of what to believe and are searching for ISIS propaganda material.

While these risks exist, one could also argue that not all counter-narratives target ideology alone. They also highlight real-life stories of insiders to highlight the human costs of engaging in violent extremism and terrorism for both for the recruit and those harmed by the group. Moreover, the primary objective of counter-narratives is to discredit violent extremist groups in the eyes of potential recruits to and save them from the costs associated with engaging in violent extremism..$^{2}$

A number of counter-narrative campaigns have been constructed and launched over the years. Quilliam, a UK-based CVE organization, in partnership with Verbalisation, launched\#NotAnotherBrother to fight the appeal of violent extremism. As part of the campaign, a short counternarrative video was released on YouTube to counter the social media recruitment of terrorist groups like ISIS.53 Following the November 2015 Paris attacks, Quilliam launched \# NousSommesUnis video to raise awareness about the dangers of violent extremism and emphasize unity between the West and Muslims.54

Jigsaw, a Google in-house think tank, piloted the "Redirect Method" to target individuals most susceptible to ISIS recruitment and redirect them to YouTube and other counter-narratives and alternative narratives that subtly undermine ISIS. While the initiative targeted ISIS recruiting themes, it did not specifically target ISIS.55To prevent UK's young Muslims from leaving to conflict zones in Iraq and Syria, a group of former extremists created a popular online cartoon called "Abdullah X." The character of Abdullah represents a young disillusioned Muslim who is initially attracted to the kind of ideology terrorist and extremist groups like ISIS espouse but who, in the end, decides not to follow the extremist path. 56

In December of 2017, ICSVE researchers launched a Facebook ad campaign using one of their counter-narratives. The ad targeted Iraq, where Facebook is currently the most widely used social media platform. The campaign led close to 1.7 million views and hundreds of specific comments related to both the counter-narrative and ISIS in general.57 International Center for the Study of Violent Extremism researchers also launched Facebook campaigns that targeted in English and Albanian language Facebook users who evidenced support for ISIS and found that they could reach this audience and engage them with the counter narrative videos..$^{8}$ International Center for the Study of Violent Extremism staff also routinely places their counter-narrative videos on YouTube and monitors the many comments. Particularly those comments in Arabic language suggest that they are reaching a target audience that engages with the videos, oftentimes in a highly heated manner. 
Although well intentioned, some counter-narrative and alternative narrative campaigns launched over the years have been heavily criticized by CVE and counter-terrorism professionals. For example, the U.S. State Department's "Think Again, Turn Away" campaign against ISIS was criticized because it heavily relied on recycling ISIS' violent footage in ways that some believed may have served to "legitimize terrorists." 59 Similarly, during the last fifteen years, the UK Home office commissioned websites and groups to argue against the use of "martyrdom" and terrorist group's call to militant jihad. Largely relying on cognitive arguments and using Islamic scriptures, these attempts were directed at presenting moderate views of Islam. However, they fell flat when it came to addressing the grievances that terrorists were so adept at using. More importantly, they fell flat in the face of al-Qaeda's, and now ISIS', use of emotionally evocative pictures, videos, and graphic images arguing that Islam, Muslims, and Muslim lands are under attack by the West, including that jihad is an obligatory duty of all Muslims and that "martyrdom" missions are called for in Islam. ${ }^{60}$

ISIS' creative and emotionally evocative use of video alongside of their advantage of social media feedback mechanisms made counter-narratives that are based on cognitive argument alone, versus emotionally evocative counter stories, pale in comparison to what ISIS puts out. In this regard, voices of disillusioned ISIS cadres, when coupled with emotionally evocative imagery, may serve more effectively as tools to discredit ISIS and their militant jihadi ideology. ${ }^{61}$

\section{Intervening in and Preventing Somali-American Radicalization with Counter Narratives}

Focus group settings are rarely seen in the terrorism/CVE literature as a source of data. This is unfortunate, as the intimate settings afforded by focus groups allow for the collection of outstanding qualitative data that can serve as the foundation for theorizing and exploring further about issues in question, such as in this case of resonance of vulnerable populations to ISIS and its recruitment tactics, as well as ways to bolster resilience to the same. ${ }^{62}$

In light of the literature findings and previous success, focus testing of the ICSVE Breaking the ISIS Brand counter narrative videos in multiple venues worldwide, ICSVE staff proposed to introduce focus groups discussions to Somali American youth led by a local Somali role model utilizing ISIS-related counter narrative videos. The purpose of the focus group testing was to:

1. Start conversations and engage with the Somali American community about violent extremism in a manner that might engage 
an audience already considered vulnerable and alienated vis-à-vis CVE efforts.

2. Open a path towards testing our counter-narrative content by engaging in conversations centered on the counter narratives to learn if and how they might have a substantial dissuading affect, as intended.

3. Discuss relevant topics they are likely to encounter from groups like ISIS as it pertains to ISIS extremist material and propaganda online.

4. Utilize the ICSVE Breaking the ISIS Brand Counter Narrative Videos to argue against the claims and promises that ISIS makes to youth. While the flow of "foreign fighters" to Iraq and Syria has decreased significantly in light of the group's recent territorial losses in Iraq and much of Syria, violent extremist groups like ISIS continue to recruit and entice vulnerable youth into violenceperhaps even accelerating their work in this regard of late. Reducing the ability of online propaganda and recruiters to entice and dupe youth is a key to further reducing ISIS or similar violent extremist group's power.

5. Offer educational training and tools to vulnerable communities to fight seductive messages that ISIS and similar violent extremist groups continue to propagate.

\section{Ethics of Counter-Narrative Production}

As researchers, we strive to develop a sound understanding of the problem we are trying to address. In other words, we aim to identify the type of message or communication campaign that is most likely to resonate with our target audience. In this regard, field research becomes a starting point to get to the desired objectives. Through our primary, field research into violent extremist groups like ISIS, we have developed an in-depth understanding of the narratives that we aim to counter and the many ways in which joiners to ISIS first learned of the group and were enticed into it-often via the Internet. In creating our counter-narratives, we carefully consider the elements of a narrative that could be most appealing to our target audience. We also consider why members of our target audience could be attracted to such narratives. ${ }^{63}$

International Center for the Study of Violent Extremism researchers have to date interviewed ninety-four ISIS and sixteen al-Shabaab related violent extremists, including their family members. Their stories take central stage in our counter-narratives. Before interviews, we make sure that we gain informed consent from our participants. International Center for the Study of Violent Extremism researcher give a special care and attention to those in prison to make sure they are speaking freely and know that they may be under surveillance that neither they nor we can control. We avoid posing any questions that could lead to the disclosure and admission of 
potential crimes or participation in illegal activities. Before the counternarratives are produced and distributed, the participants decide whether they want their faces blurred and names withheld (use pseudonyms).

\section{Methodology}

In May of 2018, ICSVE researchers conducted two focus groups in San Diego, CA. The authors relied on focus groups for data collection and content analysis for data analysis. Focus groups took place at the East African Cultural Community Center and the premises of San Diego University. The focus groups were conducted as part of ICSVE's efforts to measure and evaluate the effectiveness of its counter-narrative videos, namely "A Sex Slave for You-A gift from Abu Bakr al-Baghdadi” and "Rewards for Joining the Islamic State," in generating useful discussions about topics relevant to ISIS recruiting among the members of the Somali American community. The focus group discussion and testing were designed to gather information from the participants about the counternarrative videos and about the following outcomes:

1. To understand participants views about the so-called Islamic State

2. Assess qualitative and content-based aspects of our counternarratives (for example, authenticity of the character/actor featured in the counter-narrative)

3. To open discussions about topics that ISIS is raising in its Internet recruiting, with an alternative focus that denounces the terrorist group and its false claims

4. To raise awareness about the dangers of joining terrorist organizations like ISIS.

5. To understand the role of counter-narratives in helping to create resilience against violent extremist groups and ideologies in their respective communities.

6. To offer participants necessary educational tools to thwart the appeal of violent extremist and terrorist groups in their respective communities.

Compared to our other attempts aimed at directly reaching the same audience that ISIS targets, this particular focus group was conducted with a convenience sample of Somali-Americans in San Diego, California. ${ }^{64}$

In part, the authors chose San Diego for its large Somali American community and its history associated with violent extremism and terrorism. For instance, one of the 9/11 terrorist cells were based in San Diego. The internationally known terrorist ideologue, Anwar al-Awlaki, who was killed in a drone strike in 2011, was a San Diego cleric who actively engaged America youth, although it is not clear what his effect was during those years. ${ }^{65}$ In 2014, Douglas McArthur McCain, a former City College student, left San Diego to become an ISIS fighter, eventually 
ending up killed in Syria. His brother was indicted for making false claims to law enforcement. ${ }^{66}$ The office of the Southern District of California U.S. Attorney's office prosecuted four Somali immigrants for providing material support to $\mathrm{Al}$ Shabaab. ${ }^{67}$

We also considered the availability of a suitable and credible (within the Somali-American community) Somali American role model to run the discussions. Lastly, many young Somalis in the San Diego area remain vulnerable to the social media recruiting tactics used by terrorist groups like ISIS.

The ICSVE researchers facilitated two separate focus groups. Participants in Focus Group 1 were shown "Rewards for Joining the Islamic State," whereas Focus Group 2 participants "A Sex Slave for You-A Gift from Abu Bakr al-Baghdadi." Each group contained 5-7 participants. ${ }^{68}$ Participants were selected randomly and by relying on a snowball sampling technique (for example, by relying on friend/colleague referrals; at the gym, coffee shops, etc.). The average age of the participants in both focus groups was 26. All participants were Sunni and male. See Table 1 below for the demographic breakdown.

\section{Table 1. Demographic Data of Focus Group Participants}

Economic Status

$$
\text { Age Education }
$$

\begin{tabular}{lcc}
\hline $\begin{array}{l}\text { FG1- Participant 1 } \\
\text { Lower/poor }\end{array}$ & 21 & Some University \\
\hline $\begin{array}{l}\text { FG1- Participant } 2 \\
\text { Lower/poor }\end{array}$ & 23 & Some University \\
\hline $\begin{array}{l}\text { FG1-Participant } \\
\text { Lower/poor }\end{array}$ & 30 & Bachelor's \\
\hline $\begin{array}{l}\text { FG1-Participant } 4 \\
\text { Middle }\end{array}$ & 28 & MA or Ph.D. \\
\hline $\begin{array}{l}\text { FG1-Participant 5 } \\
\text { Middle }\end{array}$ & 30 & Some University \\
\hline
\end{tabular}

\begin{tabular}{lcc}
\hline $\begin{array}{l}\text { FG2-Participant 1 } \\
\text { Lower/poor }\end{array}$ & 27 & University \\
\hline $\begin{array}{l}\text { FG2-Particpant } 2 \\
\text { Lower/poor }\end{array}$ & 25 & $12^{\text {th }}$ Grade \\
\hline $\begin{array}{l}\text { FG2-Participant } 3 \\
\text { Lower/poor }\end{array}$ & 25 & $12^{\text {th }}$ Grade \\
$\begin{array}{l}\text { FG2-Participant 4 } \\
\text { Lower/poor }\end{array}$ & 26 & University \\
\hline $\begin{array}{l}\text { FG2-Participant 5 } \\
\text { Lower/poor }\end{array}$ & 27 & University \\
\hline Notes: Focus Group (FG); Source: Author & &
\end{tabular}


We provided the participants with a description and overall objective of the study. It clearly spelled out, risks, if any, involved in participation. They were allowed to skip any question they did not feel confident or comfortable discussing. We also informed them that they could leave the room any time they wished to do so. We also provided them with a consent form to sign, although verbal consents were approved in the case of those who were hesitant about signing the form and thereby identifying themselves. We informed them how their responses would be used. A copy of the signed consent form was kept with a facilitator and a second copy was handed to the participants. Once the video was shown to the participants, a semi-structured paper and pencil survey also containing some open-ended questions was filled out to capture participants' anonymous responses and to ensure that everyone's responses would be recorded versus only the vocal participants. Next, participants were engaged in an open, class-like discussion forum to further engage on the topics presented. We did not use a pre-testing method, as prior attitudes do not necessarily predict future behavior and there was concern that asking about prior views about the group might be seen as collecting data for law enforcement and intelligence gathering purposes. ${ }^{69}$ Future focus group testing may include pre-testing to account for participant prior knowledge or any possible bias associated with participant behavior, although this is an extremely sensitive issue in these communities.

\section{Validity, Appropriateness and Constraints of Focus Groups as Data Collection Methods}

As a qualitative research method, focus groups have and continue to be used in social sciences, including in the realm of radicalization, violent extremism, and terrorism..$^{70}$ Table 2 below reflects advantages and disadvantages of using focus groups as data collection methods. Such observations are rooted in both literature review and author observation during this particular research. ${ }^{71}$

\section{Table 2. Advantages vs. Disadvantages of Using Focus Groups as} Data Collection Method

\begin{tabular}{|c|c|}
\hline Advantages & Disadvantages \\
\hline $\begin{array}{l}\text { Time and resource effective in } \\
\text { collection information, as } \\
\text { engaging more than one } \\
\text { participant at a time } \\
\text { All participants given the } \\
\text { opportunity to participate in } \\
\text { discussions } \\
\text { - Participants given the opportunity } \\
\text { to build on each-other's ideas } \\
\text { Group interaction leading to } \\
\text { better understanding on how } \\
\text { people explain and understand }\end{array}$ & $\begin{array}{ll}\text { - } & \text { Potential Moderator induced bias } \\
\text { Participants apprehensive about } \\
\text { expressing their opinions publicly } \\
\text { Potentially exclude important } \\
\text { voices of those who are not } \\
\text { comfortable or do not accept to } \\
\text { speak publicly } \\
\text { Some participants may dominate } \\
\text { over other. Remedy: Participants } \\
\text { given equal share of participation. } \\
\text { Remain tactful with outspoken } \\
\text { members of the group and ensure }\end{array}$ \\
\hline
\end{tabular}


certain issues, including how they differ in such issues.

- Invaluable in measuring as to what changes participants support or like to see occur (for example, by viewing our counter narratives).

- Participants may be willing and motivated to take action (for example, discuss and share counter narratives) because of group interaction.

- Participants supporting eachother can help to think more creatively

- Leading to rich data that the voices of all participants are heard.

- Difficulties in distinguishing between individual view and group view

- Difficulties in organizing and ordering data for analysis

Source: Author

\section{Data Analysis}

The results section of the article contains survey results administered in our two focus groups. To analyze the responses of our participants during the focus group discussions, we relied on content analysis. Janis defined content analysis as any technique:

(a) For the classification of the sign-vehicles

(b) Which relies solely upon the judgments (which theoretically may range from perceptual discrimination to sheer guesses) of an analyst or group of analysts as to which sign-vehicles fall into which categories

(c) Provided that the analyst's judgments are regarded as the report of a scientific observer.72

There are several distinct types of content analysis, namely:

- "Sign-in vehicle analysis: Analyzing psychophysical properties of the data. For example, to assess the extent to which a topic may be emotionally appealing to our participants, we would have to examine the number of emotion-laden words used by our participants. Counting the number and types of words used is essential under this type."

- "Pragmatic content analysis: The focus of the analysis is to understand why something is said."

- "Semantical content analysis, which can be divided into three categories:

○ Designation analysis: Implies simple frequency counting analysis. In other words, it denotes frequency with which concepts, actors, institutions, etc. are mentioned. 
- Attribution analysis: It also denotes a simple frequency counting exercise; however, the focus is on counting adjectives, descriptive phrases, etc.

- Assertion analysis: A combination of designation and attribution analysis. It denotes frequency with which certain actors, concepts, institutions, etc., are characterized in a particular way."73

We started our analysis by using open coding, or the process of examining our transcripts and notes to create important categories of information based on the participants' responses. We first engaged in the process of "saturation" to "look for instances that represent a category" [or themes] with relevant sub-categories or sub-theme. " 74 Such process led to the creation of preliminary or initial coding frameworks, based on participant response readings and analysis of our notes. Before the coding, we assessed the reliability of our coding system by relying on inter-rater reliability. It serves to measure the level of agreement between the coders (researchers) and provides a quantitative index of the reliability of the code recording system we have created (Cohen's Kappa coefficient of $.70) .75$ Given the nature of our focus groups, we opted to compute a general rater reliability score, as our focus was on generating general themes within our discussion groups as opposed to focus on specific units.

Once the initial open coding process was finalized - to the extent possiblewe then moved to collecting and organizing major themes (including phrases, which later proved to be helpful when it came to utilizing the NVivo software) into a single page. This was instrumental in locating and crossing out all the duplications and drastically reducing the number of relevant categories or themes. This particular list "governed" our analysis and helped to divide the interviews into more manageable categories. In the third stage, we went back to analyzing both "meaning units" and "textural descriptions" to generate my sub-categories or sub-themes. ${ }^{76}$ In other words, a number of sub-themes or sub-categories became evident and we organized them along Janesick's formatting lines:77

Example: The question related to the feelings about ISIS included the major themes:

ISIS is evil: This major category or theme was represented in three subcategories:

(a) Un-Islamic and not based in the Quran

(b) Killing innocent civilians, and

(c) Killing other Muslims

NVivo qualitative software was instrumental in finding themes and analyzing the transcripts of the focus group answers. The software was especially useful in employing the "auto-coding" feature, which was used 
to place all answers to a certain question under one particular node. For instance, if we wanted to find out about our participants' views on particular aspect of the counter-narrative, we would click node," Q1: Reasons for liking or disliking the video." Put differently, we grouped participants' views under the aforementioned category (all answers to a single question grouped under one single category or page). This approach represented the quickest and most efficient way to look for patterns and more closely examine any pertinent themes, given they were all grouped under the same category.

We used other important features of NVivo's "auto-coding," such as "word frequency," to look for most commonly utilized words by our participants (for example, "Un-Islamic, evil, etc.). Moreover, through this particular feature, we were able to further adjust our query from "Search for Exact words" to "Search for synonymous words." This gave us a wide array of word options and tools to better organize and find new emerging themes (See sample output to one of the questions asked during the focus group testing).

Once we completed our "auto-coding" and ran the "word query," we continued to manually analyze our transcripts, despite the fact that the initial words derived from the queries were instrumental in generating models demonstrating relationships and patterns that we ought to be looking for or expect to find in our respective transcripts.

\section{Results and Discussion}

The focus group testing was an invaluable exercise in understanding how certain members of the Somali-American community in San Diego, CA, interpret and respond to terrorist violence, specifically as discussed through the lens of ICSVE-produced counter-narratives. Despite being an all-male sample, a majority of the respondents reported negative emotional responses to what they heard from the ISIS defector, especially as they discussed about the rape of Syrian women. When participants in Focus Group 2 were asked about their views on using Yazidi women, or any other women for that matter, as sex slaves, all respondents used adjectives such as disturbing, shocking, depressing, etc. to describe them. The Chart 1 below depicts Focus Group 2 participant aggregate views and feelings when discussing "A Sex Slave for You-A Gift from Abu Bakr alBaghdadi" video and the use of women as sex slaves, with a majority of them using adjectives such as angered (13\%), heartbreaking (22\%), etc. 


\section{Chart 1: Opinions About "A Sex Slave for You-A Gift from Abu Bakr al-Baghdadi" and Use of Yazidi Women as Sex Slaves}

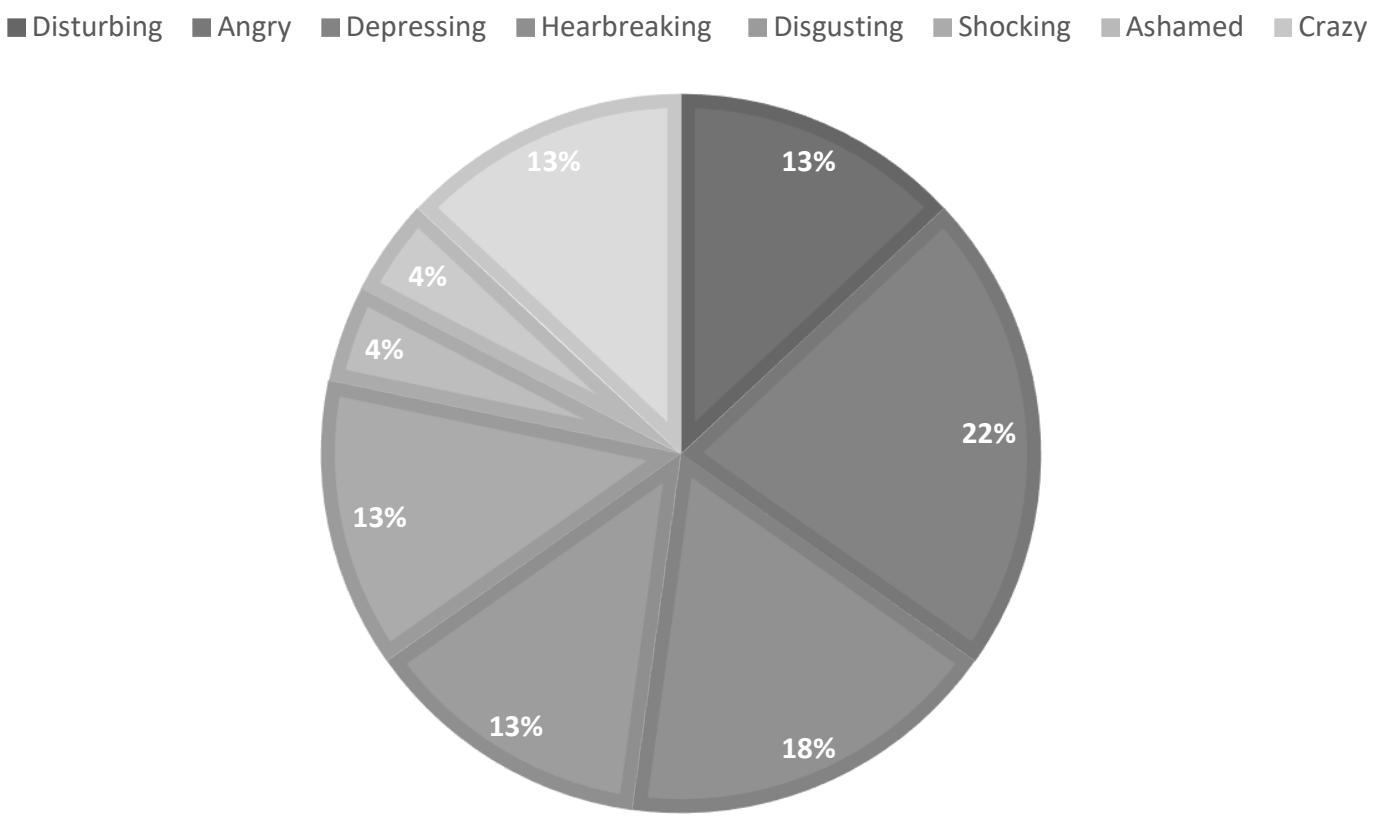

Source: Author

Also consider the following Focus Group 1 participants' emotional responses to the question of "What do you think about the defector (Abu Ghazwan) saying he suffers post-traumatic stress disorder (PTSD)," when viewing "Rewards of Joining the Islamic State' counternarrative video" (The Chart 2 below contains the frequency of adjectives used to describe their views and feelings):

- "I think that anyone would feel the same way."

- "If you experience things like this, it's going to have an effect on you. It's part of human nature to deal with nightmares after something traumatic." 


\section{Chart 2: Abu Ghazwan (Video) Suffering Post-Traumatic Stress Disorder (PTSD)}

$\square$ Crazy $\square$ Depressing $\square$ Heartbreaking $\square$ Horrible $\square$ Intense $\square$ No pity $\square$ Saddening $\square$ Tragic $\square$ Unsettling

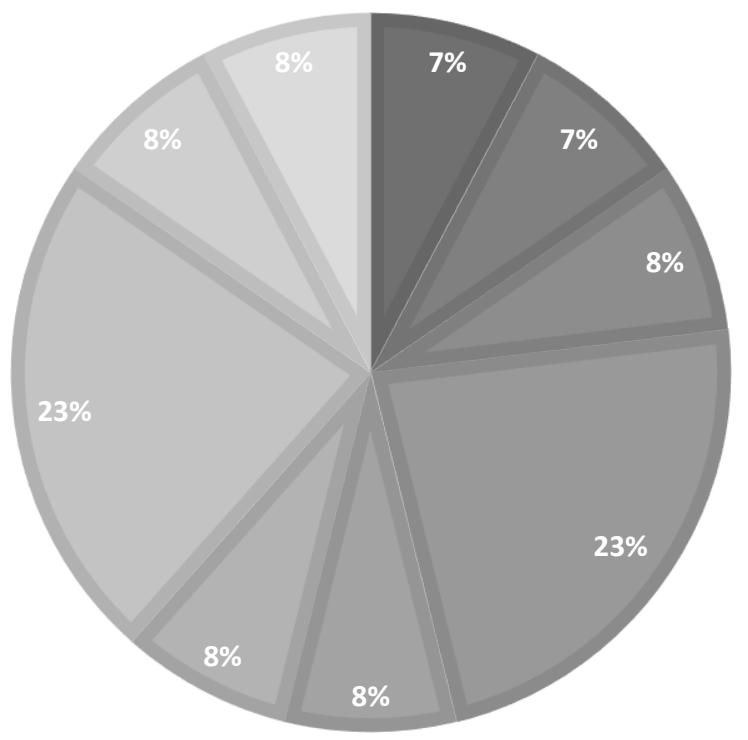

Source: Author

The findings run contrary to the assumption that men are less likely to show discomfort, fear, or disgust-or are in "total control of their emotions"-when interacting with violent content or narratives. ${ }^{8}$ That said, it would be wrong to assume that they are expressing such sentiments "as much as women" might, as the sample did not include any women. Moreover, as shown above, participants discussed the issue of PTSD through accumulation of hardships, arguably rooted in the experience of war, which they themselves can relate to through either personal or collective memory of the war back in their homeland (Somalia). Equally important and strictly speaking in the context of participant responses with respect to rape, some Somali Americans may be vulnerable to being manipulated emotionally about rape, as past al Shabaab recruitment tactics manipulated Somalis to return to their homeland (Somali) to fight jihad to prevent the rape of Somali women. In this regard, the defense of women's honor, or a belief system among many Arabs and Muslims that valorizes women's honor, was clearly reflected in participant responses.

\section{Focus Group 1 Survey Data}

(Frequency of words used to express emotions, feelings, etc. by the participants concerning "Rewards of Joining the Islamic State" video. For example, unbelievable (12\%), tragic (9\%), terrible (6\%), and wrong (6\%) were the most frequently selected descriptors). See Chart 3 for a breakdown. 


\section{Chart 3: Opinions About "Rewards of Joining the Islamic State" Video}

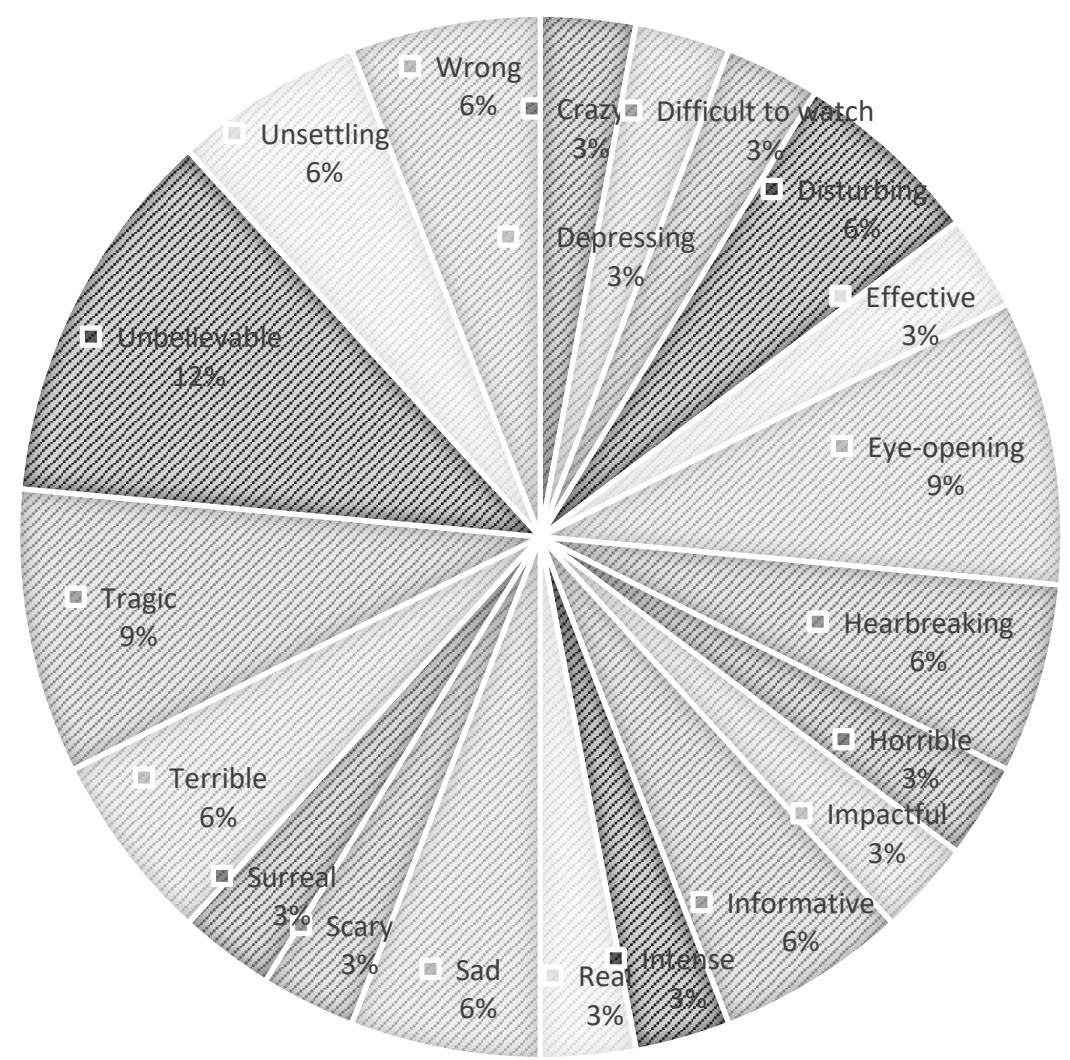

Source: Author

Four of the five respondents who chose to identify themselves in the survey and during discussion thought the video was credible and that the main protagonist (Abu Ghazwan) featured in "Rewards for Joining the Islamic State" was telling the truth when discussing his experiences inside the ISIS. In viewing "A Sex Slave for You-a Gift from Abu Bakr alBaghdadi," four out of five participants believed the speaker was credible (See Table 3). Four of the participants noted:

- "Yes, I think it's true; no one would make up things like this."

- "His tone changes when he talked about his mother, so I think it's real based on his emotions I can hear."

- "You just can't make things up like this. Even when he talked about the religion, he used the right terminology, like "Allah Azzawajal."

- Four out of five also believed the speaker was telling the truth (See table that follows), with some remaining reserved in their views. 
- "Only God knows."

- "Hard to tell but at the same time it's realistic."

- "We couldn't see his face, so in many ways I have some doubt about how real it is."

- "One thing for sure is that the mothers in the video where not real."

- "The clips were real and geographic region can attest to that. Only someone from the region would know if it's real or not."

Some participants, however, questioned the speaker and video's authenticity, asking if they were produced by Hollywood or some government-affiliated entity. They also stated that videos would look more authentic if the defector faces were actually shown:

- "Yes, look at some of the T.V. shows that are out there regarding terrorism they all look real, but it's made it Hollywood."

- "I think it would be more real if he showed his face, and maybe kept it real and just say he did some raping himself."

Indeed, we already have evidence suggesting that in the case of countermessages that bear the seal of a government entity (for example, U.S. State Department), the effectiveness of such counter-messaging may be rendered partially, or entirely, ineffective due to such symbolic association. However, ICSVE researchers aimed to avoid this by openly disclosing in its branding the authorship of the video (for example, using the ICSVE seal on the video and clearly attributing authorship to the nonprofit). However, it was interesting to see that some participants still doubted the production authenticity of the video. The suggestion to show the faces of the defectors is an important but difficult, if not impossible, request to achieve due to the interviewee's own security concerns. On a positive note, despite some doubts on the authenticity of the speaker due to their faces being hidden from the camera, a majority of the participants expressed confidence in the authenticity of the ISIS defectors presented in the counter-narrative, and even those that had doubts strongly engaged with the material presented in it. Thus, despite any doubts, everyone engaged with the material that the videos elicited from the group. Even the doubters participated in the discussions, suggesting that they may have taken the speaker seriously after voicing potential doubts about his authenticity and having the chance to have their questions answered by the discussion group leader. 


\section{Focus Group 2 Survey Data}

The Table 3 below contains Focus Group 2 participant agreement, as measured on a 1-7 scale, on a set of questions pertaining to "Rewards for Joining the Islamic State” video.

\section{Table 3. Participant Agreement on "Rewards for Joining the} Islamic State" Video

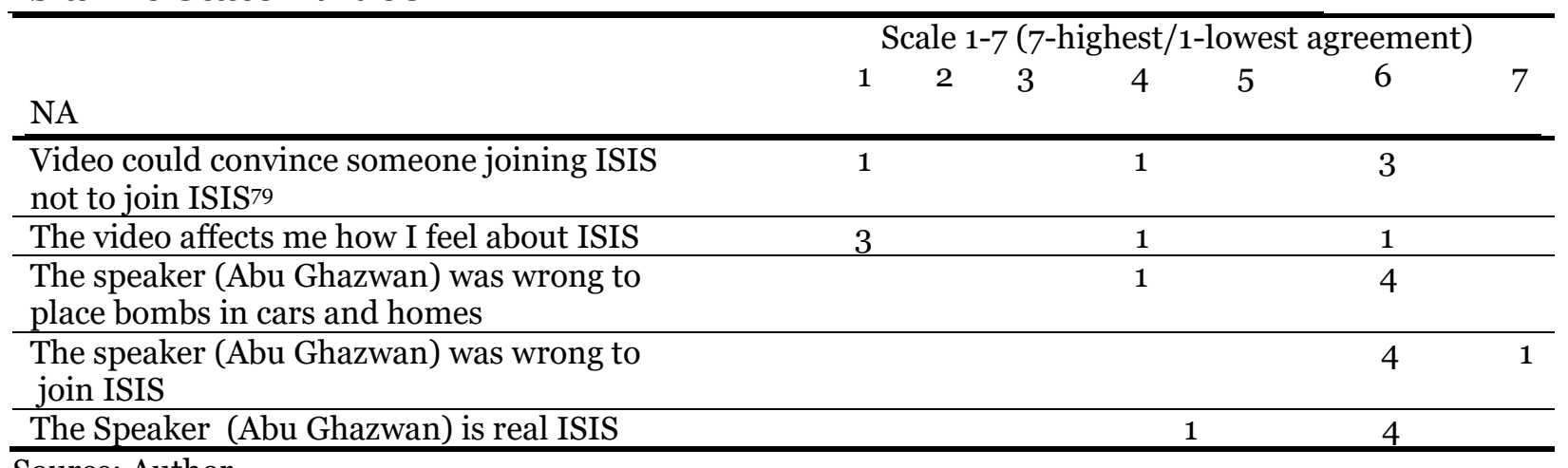

Source: Author

The results of the survey, as shown in the Table 4 and Table 5 , indicate an unfavorable view of ISIS. ${ }^{80}$ For example, when looking at the tables, all participants in Focus Group 1 believe that ISIS is a terrorist organization and that ISIS does not adhere to Quran and Islamic principles. Moreover, all of the participants in both focus groups during discussions expressed that violence perpetrated by ISIS, namely suicide bombings and violence against civilians and other religious and ethnic groups, is never justified. A small share of the participants, however, expressed frustration over politics and the government of Iraq, including U.S. foreign influence in the Middle East. Consider the following statements made by some participants when addressing a narrative presented by Abu Ghazwan in the "Rewards for joining the Islamic State" counter-narrative as well as how some participants echoed the sectarian issues that in part drove Abu Ghazwan to join ISIS:

- "They left the Shia friends go. That's how their government works. If you are a Shia, you're off the hook. And if you are a Sunni or something else, you are going to die in prison."

- "He was mad at the government, so we need to look at the government and the people who are not just; they are the ones causing the problem."

- "To some degree I think it was the leadership and government as well [responsible], who are not just to certain groups that cause this problem." 
- "Well we know our government is responsible for all the troubles in almost every country. We can use violence, but we need to address the root of the problem."

- "Hell, no, they never did that, that how you lose your license bro you can't say terrorism and Jewish or Christians in the same sentence."

\section{Focus Group 1 Survey Data}

The Table 4 below contains Focus Group One participant opinions, as measured on a 1-7 scale, about ISIS.

\section{Table 4. Focus Group 1 Participant Opinions about ISIS}

Scale 1-7 (7-highest/1-lowest agreement)

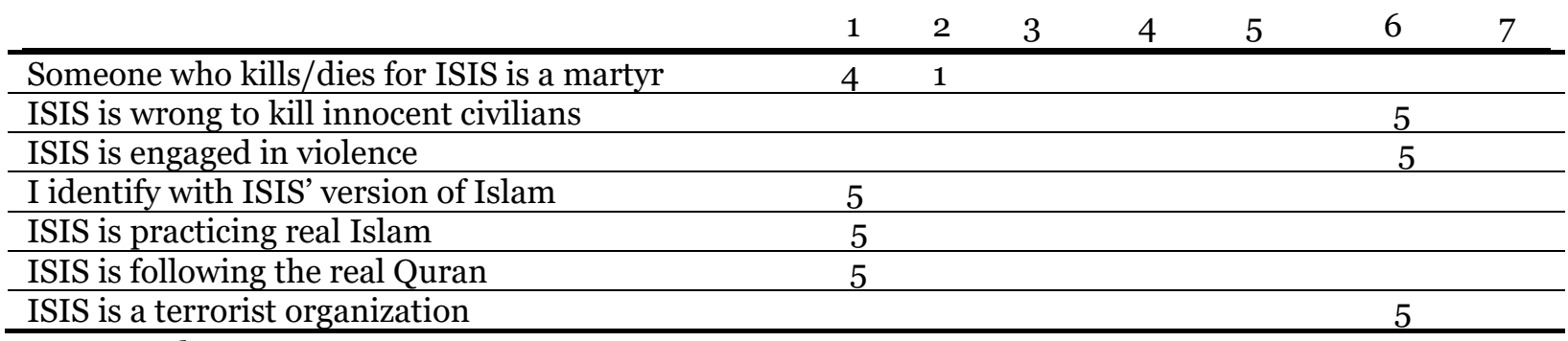

Source: Author

\section{Focus Group 2 Survey Data}

The Table 5 below contains Focus Group Two participant opinions, as measured on a 1-7 scale, about ISIS.

\section{Table 5. Focus Group 2 Participant Opinions about ISIS}

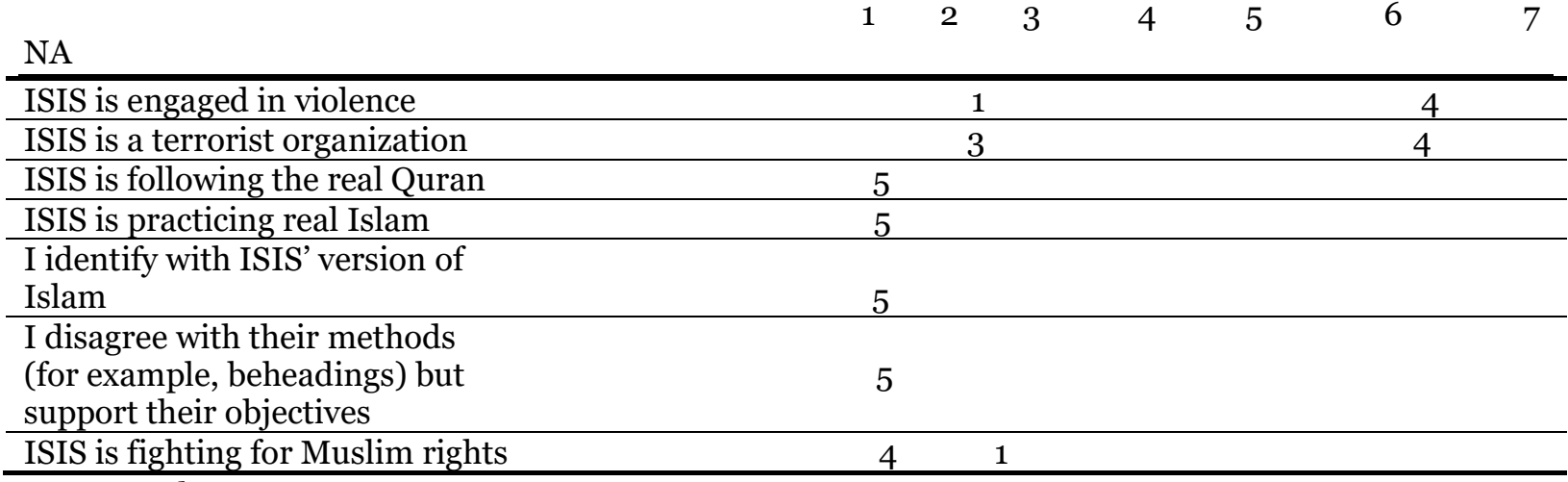

Source: Author 
Although opinions on the issue remain mixed, similar to our focus groups findings in Zarqa and Irbid in Jordan, sectarian and religious favoritism, lack of government responsiveness, and corruption are often blamed for a range of ills, including the rise of ISIS, though these conditions are not entirely unrealistic. ${ }^{8}$ The issue here is whether participants believe that groups like ISIS can help to address the contentious social, economic, political, etc. issues or if they should be avoided entirely as offering any real and practical solutions to such issues. Exploring and understanding such sentiments is crucial given that ISIS' existence and durability lies in its ability to apply its ideology and tactics to the grievances of Sunni Muslims around the world. It is how it manages to garner support for its cause. As also evidenced in our research in other parts of the world, the appeal and attractiveness of ISIS' non-violent, slickly produced video material and propaganda-those that feature some of the themes described by our participants, namely the themes of brotherhood, victimization, community, religious prosecution, etc.-among those who do not profess or sympathize with the group remains especially worrisome.

One of the key objectives of the focus group testing was to highlight ISIS' hypocrisy in claiming to be representing the Muslim cause or creating a Caliphate run by Muslim ideals in the territory of Iraq and Syria. All respondents, in both focus groups, understood the intended message of our counternarratives. Likewise, they expressed gratitude for having been invited into a safe space where they could openly debate some of the issues groups like ISIS raise. Although a small and non-representative sample, there are several implications associated with such findings. Firstly, it speaks to the quality of the video in terms of both production and the manner in which the anti-ISIS message was delivered. Secondly, contrary to some assumptions, counternarratives that contain violent footage taken from ISIS do not necessarily serve to encourage or glorify the ISIS cause or attacks, and may, as we were able to observe, open discussions where horror, disgust, and anger over ISIS tactics dominates. Chiefly, such findings lend little credibility to claims made by some that any use of material produced by ISIS may serve "as a direct or indirect encouragement for the commission, preparation, or instigation of acts of terrorism." 82 No participant raised concern over such an issue. Instead, the emotionally evocative material that serves ISIS in their recruiting tasks also served us in our ability to open a lively discussion. It is in part through such evocative material that participants thought about and discussed extremely disturbing socio-political issues-to which ISIS claims to have answers-albeit violent answers.

Lastly, ISIS-produced videos and content greatly outnumber counternarratives produced by governments and other entities such as ours. Given the high-volume production of ISIS material in relation to countermessages produced by governments and other entities, individuals in the 
West often have no idea about, or misunderstand the purpose and use of counter narratives. For example, as mentioned above, counter-narratives may to a degree serve to mimic ISIS materials but do not in any way glorify ISIS. This misunderstanding is sometimes evidenced among counter terrorism experts who view our or similar videos, clearly not reflected in participant responses. Examples such as these indicate that we need to continue to engage in sustained coverage of counter-narratives such as ours.

\section{Focus Group 1 Survey Data}

As stated earlier in the article, it is highly likely that most, if not all, participants in the focus groups already had biased or unfavorable views towards ISIS. In fact, when we asked Focus Group 1 "If the counternarratives could convince somebody considering joining ISIS not to," two out five doubted the utility of the counter-narrative, primarily because they already held unfavorable views towards ISIS. In this regard, several of the respondents noted:

- "Not really. I never thought ISIS had any good in them."

- “They are evil.”

- "I don't think about them at all."

The aforementioned may lead some to question the effectiveness of counter-narratives. That said, while some of the participants were reassuring the fellow group members that they were not vulnerable to recruitment, they also strongly engaged with the material. This may also suggest that ISIS could also engage them. In other words, although some participants claimed that ISIS could never influence them, we were able to observe strong emotional responses to the ISIS material. This suggests that it is emotionally charged material and important to the participants. However, in our case, it was presented in a way that discredited ISIS or any violent extremist group as having credible answers. This was the main point of the exercise.

There is a caveat in making such assumptions, however. First, most of the focus group participants reported having negative attitudes and opinions about ISIS. This cannot be dismissed in determining their potential for recruitment. However, we must also keep in mind that reporting unfavorable opinions about ISIS is the expected response in today's security environment for minority Muslims, first and second-generation immigrants. Moreover, most would be hesitant to openly admit in a first encounter that they harbor positive sentiments about ISIS out of fear that the researchers are informants or that they could somehow be harmed by speaking candidly about it. 
Secondly, just because our focus group participants engaged with our counter-narratives, it does not necessarily mean that they would engage with material that ISIS would show them. Namely, there are a number of predictors that determine how audiences interact with the material. While such contentions may hold true, based on our interactions with SomaliAmerican population, we also know that many do engage with ISIS material and endorse parts of their ideology, which makes them vulnerable to further ideological indoctrination and recruitment.

One should highlight the utility of openly pointing out lies inherent in terrorist propaganda and correcting any doubts and misinformation that might be circulating in the participants' everyday lives. One must also stress the utility of creating a safe space in which a vulnerable audience can even discuss ISIS' claims. The voices of defectors, including the voices of ISIS victims, are especially powerful if shown in safe environments, where a guided discussion can take place. Arguably, building wellinformed and resilient communities is essential to countering violent extremist appeal.

One of the goals of the counter narrative videos is to present a learning opportunity to youth in which they can learn not through their own negative experiences but vicariously as well, namely from others who faced similar choices and made serious mistakes in joining ISIS [long] before them. When resonating and evoking strong responses, it enables the viewers to imagine themselves accepting the ISIS claims and ending up in the bad circumstances that are being narrated to them in the video. While they may strongly identify with the extremist rhetoric, mainly rooted in victimization narrative, it gives them a chance, without having to commit a mistake themselves, to learn that trying to solve the victimhood dilemma through solutions offered by ISIS is unlikely to end well. Counternarratives such as ours also explore feelings, and not just words. This is the reason why they are highly likely to influence vulnerable individuals to learn from other people's negative experiences and mistakes. Should they be confronted with and lured into ISIS "remedies" at some point in their lives, the counter-narratives also serve to offer additional tools to the participants to potentially address and advise other vulnerable individuals.

The ISIS cadres interviewed in the Breaking the ISIS Brand Counter Narrative Project, including the ones shown to the focus group participants, often share and discuss their own psychological needs and sufferings. They attempt to make sense of their experiences leading to and inside of ISIS and what it means now to not only themselves (for example, spending prison time, having traumatic experiences, etc.) but to others as well (for example, pain, suffering, etc. they may have caused to others). By viewing such material, the focus group participants engaged in an 
interactive learning process, whereby the process itself facilitated a narrative exchange. It is through such processes that focus group participants not only discussed personal experiences but may also have possibly facilitated impactful disengagement and radicalization processes involving others. One respondent shared a personal experience related to the rape of a relative sparked after watching "A Sex Slave for You-A Gift from Abu Bakr al Baghdadi” video. The personal story of the participant added a degree of relatedness to the defector story, including authenticity to the story told by him. The respondent comments and reactions by other discussants are captured below:

- "Yeah bro why not, how the [expletive] are they being held captive [Yazidi sex slaves] and caught in the first place. It's [expletive] other man who let that happen. So, since they are being raped now, that means next time protecting your [expletive] women. I would die before telling that [expletive] happen."

- "Yo calm down with that [expletive] man! I have a family member who was raped and beaten to death and it has nothing to do with not being able to protect them."

- 'I'm sorry to hear that bro. I don't mean it's right for it to happen. But I'm sorry to hear that. Very emotional (10-minute break) participant in tears! Do you want to talk about how you feel?"

- "No, I'm okay. Just want to say that you can lose someone you love and close to you by rape and force. It has nothing to do with ISIS or politics, or Sunni and Shia. If I was there I would do anything to change the outcome I would give my life bro! But Allah didn't place us there to stop it or have the ability to even know about it. He knows what's best."

Arguably, throughout both focus groups, the videos-even if some at first doubted their authenticity-were able to reach vulnerable youth and open them up to in-depth discussions of the topics that ISIS tries to use to ensnare them on the Internet. All the participants shared their unfavorable view of ISIS. Some were either already against ISIS before engaging with the materials or clearly became so when confronted with the troubling experiences of the ISIS cadres denouncing the claims ISIS had made to them and the clear reality that joining had not in any way enhanced their lives.

\section{Limitations}

Several important limitations apply to the focus group findings. It seems likely that most, if not all, participants who took part in the focus group testing already had unfavorable views towards ISIS in general. However, it 
is also likely that subjects may have particular beliefs and views that align with ISIS' claims. This can make them open to manipulation and more favorable towards ISIS. Our goal was the opposite in this regard: To challenge anything where they might believe ISIS was in the right. Likewise, given the security environment in which Somali American youth feel suspicious of CVE efforts, the sample participants might have been hesitant to truthfully share their sentiments about ISIS and its ideology. In fact, some admitted to the focus group moderator that there are no forums where they can speak openly and safely about these issues without suspecting that, others might be informants or that their views will be misconstrued in some way, shape. This leaves them vulnerable to not fully developing their resistance and resilience to terrorist group recruitment.

It is likely that in any such sample there may be some who fall on a spectrum: Those who are truly radicalized and already supportive of ISIS and its ideology, but unlikely to openly admit it; those who are at risk of radicalization; those who hold unfavorable views about ISIS; and those who are simply neutral about ISIS. Moreover, the focus group served to test the utility of counternarratives in supporting negative attitudes towards ISIS or increasing negative existing attitudes towards ISIS as well as challenging any views that might support ISIS, but it did not measure the possibility of interesting focus group participants further in ISIS and its ideology.83 It also did not utilize control and comparison groups, which could be done in the future. This would entail experimental designs (for example, the treatment, and the control groups with random assignment) or quasi-experimental designs (post-test only, time-series design etc.). ${ }^{84}$

Lastly, while many participants might have already had unfavorable views towards ISIS and might not favor or succumb to extremist narratives, the focus group testing served as an opportunity for the participants to access and learn about educational resources that openly target violent extremist groups like ISIS. Similarly, as researchers, we gained additional knowledge on the most appealing and resonating aspects of the video. The group discussions also presented an opportunity for the participants to talk about difficult topics and debate claims made by ISIS. Participants would have generally avoided discussing them if they judged the environment not to be safe. The participants were also offered information that they can use the videos to target and educate others who might be vulnerable to such extremist narratives, namely serve as influencers to magnify the impact of the counternarratives.

\section{Conclusion}

This article highlighted the results of the ICSVE counter-narrative focus group testing administered with a small sample of Somali youth in San Diego, California. It also presented methodological argument, or a case study, in the use of counter narratives as an effective Counter Violent 
Extremism (CVE) tool. 85 The small sample sizes do not allow us to generalize the findings. However, the research is important in measuring attitudes towards violent extremist groups like ISIS, which remains largely under-researched in the context of Somali-American community in the United States. The goal was to offer and test for the Somali-American community in San Diego tools to fight the appeal of violent extremist groups in their respective communities. Our research shows that when administered in a focus group setting with a trusted Somali focus group moderator, such tools can be highly effective in generating invaluable discussions around issue related to ISIS recruitment and ISIS-related radicalization.

This research is considered a "community-based participatory research," namely the one in which Somali-Americans served as core members of our research team and ensured that our research design and objectives were closely aligned with those of the participant community. We also attempted to ensure that the participants had a strong stake in understanding and preventing violent extremism in their respective communities. In addition, by engaging in community-based participatory research, we strove to ensure that the participants do not feel as though they are being unfairly targeted or stigmatized in relation to our research objectives. ${ }^{86}$ In that regard, we also judged the effort a success as participants expressed gratitude for being invited to participate as well as given the opportunity of a safe environment in which to discuss difficult topics related to ISIS and violent extremism in general. It is our view that without the emotionally evocative nature of the videos such discussions may have fallen flat, but given the videos, lively discussions took place.

The findings do not suggest that we certainly reached a pool of "at-risk" individuals for radicalization, including radicalization leading to violence, as we have in our previous studies. ${ }^{87}$ Such findings, however, should not prevent us from concluding that though at times with narrow limits and applications, counter-narratives remain one among many important tools in countering the appeal of violent extremism. While we realize this is just one tool among many, we, in fact, acknowledge that assuming primacy of any CVE tool would be detrimental to the CVE objectives we are trying to address, both in terms of response and prevention efforts. However, given the scale of participant engagement in focus group discussions, we were able to indeed touch on the same issues that ISIS attempts to manipulate in its recruitment efforts. Arguably, if not already turned off, the participants in our discussions were even further turned away from ISIS and bolstered by the counter-narratives and ensuing discussions in those negative views of ISIS. Thus, we feel confident that these tools can be used if carried out in a safe and careful way to effectively fight and disrupt ISIS recruitment. They can be used for both interventions and prevention of ISIS-related radicalization in the Somali American community. 
Our focus group testing with the Somali-American community members was carried out in conjunction with several other research studies conducted by our center worldwide. In all instances, in our experience, the emotional and conversational nature of targeted prevention is best carried through face-to-face interactions and through interpersonal activity, in which counter-narratives play a crucial role in facilitating such engagement and interpersonal activity. ${ }^{88}$ However, given the widespread use of Internet learning, we also acknowledge that such materials can also be instrumental online, although lacking the personal care and touch that a discussion moderator can offer. Given that ISIS was able to leverage social media feedback mechanisms to contact those who respond to their online material, the same should be possible for those wishing to use the counter-narrative videos in a similar manner-contacting those who respond to them for further online discussions, possibly leading to offline meetings. Future research will focus on more targeted efforts, and ideally with other vulnerable and "at-risk" individuals for radicalization, including radicalization leading to violence. Our efforts with respect to the members of American-Somali community focused on small wins over the long haul against ISIS and other similar extremist groups. 


\section{Endnotes}

${ }^{1}$ United Nations, "Greater Cooperation Needed to Tackle Danger Posed by Returning Foreign Fighters, Head of Counter-terrorism Office Tells Security Council," November 28, 2017, https://www.un.org/press/en/2017/sc13097.doc. htm.

${ }^{2}$ Counterterrorism, Counterintelligence, and the Challenges of Going Dark, Before the Senate, Select Committee on Intelligence, 114th Cong. 1st (2015) (statement of James B. Comey, Director, Federal Bureau of Investigation).

3 Alexander Meleagrou-Hitchens, Seamus Hughes, and Bennett Clifford, "The Travelers: American Jihadists in Syria and Iraq, "Program on Extremism: The George Washington University, February 2018, https://extremism.gwu.edu/ sites/g/files/zaxdzs2191/f/TravelersAmericanJihadistsinSyriaandIraq.pdf. 4 Ibrahim Hirsi, "Why the Somali Community in the Twin Cities is So Much More Politically Successful than the Ones in Columbus, Ohio," MinnPost, April 3, 2017,. https://www.minnpost.com/new-americans/2017/04/why-somali-community-twincities-so-much-more-politically-successful-one-colum/.

5 Laura Yuen, Mukhtar Ibrahim, and Sasha Aslanian, "Called to Fight: Minnesota's ISIS Recruits," MPRnews, March 25, 2015, https://www.mprnews.org/story/2015/03/25/minnesota-isis.

${ }^{6}$ Mukhtar M. Ibrahim, "ISIS Trial in Minnesota: What you Need to Know," MPRnews, May 6, 2016, https://www.mprnews.org/story/2016/o5/o6/isis-trial-minnesota-faq. 7 Mike Eckel and Harun Maruf, "Why He Chose to Leave this Good Land? Islamic State Beckons and Somali Americans Again Struggle with Radicalization," VOA, December 1, 2014, https://projects.voanews.com/isis-recruit-somali-americans/.

8 Ray Sanchez, "Man Sentenced to 30 Years for Trying to Bomb Oregon Christmas-Tree Lighting," CNN, October 1, 2014, https://www.cnn.com/2014/10/01/justice/oregonterror-sentencing/index.html.

9 Maureen Kocot, "Authorities Warn ISIS Propaganda is Targeting Ohioans," TV1O, May 10, 2018, https://www.10tv.com/article/authorities-warn-isis-propaganda-targetingohioans.

${ }^{10}$ Anne Speckhard and Ardian Shajkovci, "Will ISIS Live on in Iraq?” The Hill, March 11, 2018, http://thehill.com/opinion/international/377621-will-isis-live-on-in-iraq.

${ }^{11}$ Anne Speckhard and Ardian Shajkovci, "After a New Massacre, Charges that ISIS is Operating with Assad and the Russians, Daily Beast, August 9, 2018, https://www.thedailybeast.com/how-assad-isis-and-the-russians-cooperated-to-carryout-a-massacre?ref=author.

12 Speckhard and Shajkovci, "After a New Massacre."

${ }^{13}$ Appendix A contains background information on the ICSVE.

${ }^{14}$ Farah Abdiqani, "Extremism in MN: Why are Somali-American Kids Joining Islamists Abroad?” SSRN, February 22, 2016, https://papers.ssrn.com/sol3/papers.cfm?abstract_id=2736410; Cawo Abdi, "Disclaimed or Reclaimed? Muslim Refugee Youth and Belonging in the Age of Hyperbolisation," Journal of Intercultural Studies 36, no. 5 (August 2015): 564-578; Peter Bergen, David Sterman, Alyssa Sims, and Albert Ford, "ISIS in the West: The Western Militant Flow to Syria and Iraq," New America, March 2016, https://static.newamerica.org/attachments/12898-isis-in-the-west-march-2016/ISIS-inthe-West-II.8aoc30a894ec4b96a8340d5b26779456.pdf.

15 Abdiqani, "Extremism in MN."

${ }^{16}$ Erroll Southers and Justin Hienz, "Foreign Fighters: Terrorist Recruitment and Countering Violent Extremism (CVE) Programs in Minneapolis-St. Paul," CREATE Homeland Security Center, April 2015, https://priceschool.usc.edu/files/2015/05/Foreign-Fighters-Terrorist-Recruitment-andCVE-in-Minneapolis-St-Paul.pdf. 
${ }^{17}$ Andrew Liepman, "Violent Islamist Extremism: Al-Shabaab Recruitment in America," National Counterterrorism Center, March 11, 2009, https://www.hsgac.senate.gov/imo/media/doc/o31109Liepman.pdf.

18 Anne Speckhard, "How do We Defeat ISIS? Less Bombs, More Social," The Hill, July 6, 2016, https://thehill.com/blogs/pundits-blog/international-affairs/286476-how-do-wedefeat-isis-less-bombs-more-social.

19 Dina Temple-Raston, "For Somalis in Minneapolis, Jihadi Recruiting is a Recurring Nightmare," NPR, February 18, 2015, https://www.npr.org/2015/02/18/387302748/minneapolis-st-paul-remains-a-focus-ofjihadi-recruiting.

${ }^{20}$ Anne Speckhard, personal communication with Somali CVE professionals, 2017.

${ }^{21}$ Allie Shah, "Minneapolis Sough High Clash Exposes Somali-and-African-American

Student Rift," Star Tribune, February 23, 2013, http://www.startribune.com/south-highclash-exposes-somali-and-african-american-student-rift/192633391/.

22 Anne Speckhard, personal communication with Somali CVE professionals, 2017.

${ }^{23}$ Robyn Kriel and Briana Duggan, "Al Shabaab Faction Pledges Alleigance to ISIS," CNN, October 23, 2015, https://www.cnn.com/2015/10/22/africa/al-shabaab-factionisis/index.html.

24 Joyce Hackel, "In Minnesota, ISIS May be Building on the Recruiting Networks Once Used by Other Terrorist Groups," PRI, March 27, 2015,

https://www.pri.org/stories/2015-03-27/minnesota-isis-may-be-building-recruitingnetworks-once-used-other-terror-groups; as cited in Erroll Southers and Justin Hienz, "Foreign Fighters: Terrorist Recruitment and Countering Violent Extremism (CVE) Programs in Minneapolis," https://priceschool.usc.edu/files/2015/05/Foreign-FightersTerrorist-Recruitment-and-CVE-in-Minneapolis-St-Paul.pdf.

25 Southers and Hienz, "Foreign Fighters."

${ }^{26}$ Hussein Solomon, "Somalia's Al Shabaab: Clans vs Islamist Nationalism," South African Journal of International Affairs 21, no. 3 (October 2014): 351-366, http://dx.doi.org/10.1080/10220461.2014.967286.

27 William McCants, "The Polarizing Effect of Islamic State Aggression on the Global Jihadist Movement," Combating Terrorism Center 9, no. 7 (July 2016): 20-22, https://ctc.usma.edu/app/uploads/2016/o8/CTC-SENTINEL_Vol9Iss78.pdf. ${ }^{28}$ Southers and Hienz, "Foreign Fighters."

29 Cawo Abdi, "Disclaimed or Reclaimed? Muslim Refugee Youth and Belonging in the Age of Hyperbolisation," Journal of Intercultural Studies 36 no. 5 (August 2015): 564578, https://doi.org/10.1080/07256868.2015.1072905; Farah Abdiqani, "Extremism in MN: Why are Somali-American Kids Joining Islamists Abroad?," February 22, 2016, https://papers.ssrn.com/sol3/papers.cfm?abstract_id=2736410.

$3^{\circ}$ Speckhard, personal communication with law enforcement officials in St. Louis Park, MN, 2016.

${ }^{31}$ Stevan Weine, John Horgan, Cheryl Robertson, Sana Loue, Amin Mohamed, and Sarah Noor, "Community and Family Approaches to Combating the Radicalization and Recruitment of Somali-American Youth and Young Adults: A Psychological Perspective," Dynamics of Asymmetric Conflict 2, no. 3 (2009): 181-200.

32 Weine et al., "Community and Family Approaches."

33 Bonnie Washuk, "Lewiston Police Hoping to Hire Officers from Somali Community," Sun Journal, May 22, 2015, http://www.sunjournal.com/lewiston-police-hoping-hireofficers-somali-community/.

34 Stevan Weine, John Horgan, Cheryl Robertson, Sana Loue, Amin Mohamed, and Sarah Noor, "Community and Family Approaches to Combating the Radicalization and

Recruitment of Somali-American Youth and Young Adults: A Psychological Perspective," Dynamics of Asymmetric Conflict 2 no. 3 (December 2009), https://doi.org/10.1080/17467581003586897.

35 Steven R. Corman, "Understanding the Role of Narrative in Extremist Strategic Communications," September 2011, in Countering Violent Extremism: Scientific Methods and Strategies, eds., Laurie Fenstermacher and Todd Leventhal, 37, http://www.nsiteam.com/pubs/U_Counter\%20 
Violent\%20Extremism\%2oFinal_Approved\%2ofor\%2oPublic\%2oRelease_28Oct11v3.pd f.

${ }^{36}$ Corman, "Understanding the Role," 6.

37 Alex P. Schmid, "Al-Qaeda's 'Single Narrative' and Attempts to Develop Counter-

Narratives: The State of Knowledge," International Centre for Counter-Terrorism

(ICCT), January 2014, https://www.icct.nl/download/file/Schmid-Al-Qaeda's-SingleNarrative-and-Attempts-to-Develop-Counter-Narratives-January-2014.pdf.

${ }^{38}$ Bennett Furlow and Goodall H.L. Jr., "The War of Ideas and the Battle of Narratives: A Comparison of Extremist Storytelling Structures," Cultural Studies, Critical

Methodologies 11, no. 3 (2011): 215-223, https://doi.org/10.1177/1532708611409530.

39 Dina Al Raffie, "Whose Hearts and Minds? Narratives and Counter-Narrative of Salafi Jihadism," Journal of Terrorism Research 3, no. 2 (September 2012): 13-31, http://dx.doi.org/10.15664/jtr.304; Carsten Bockstette, "Taliban and Jihadist Terrorist Use of Strategic Communication," Connections: The Quarterly Journal 8, no. 3 (2009): 1-24, http://dx.doi.org/10.11610/Connections.08.3.01.

${ }^{40}$ Kurt Braddock and James Price Dillard, "Meta-analytic Evidence for the Persuasive Effect of Narratives on Beliefs, Attitudes, Intentions, and Behaviors," Communication Monographs 83, no.4 (2016); 1-24, 18, https://doi.org/10.1080/03637751.2015.1128555; Garth Davies, Christine Neudecker, Marie Ouellet, Martin Bouchard and Benjamin Ducol, "Toward a Framework Understanding of Online Programs for Countering Violent Extremism," Journal for Deradicalization 6 (Spring 2016): 51-86, 51, http://journals.sfu.ca/jd/index.php/jd/article/view/43.

${ }^{41}$ Kurt Braddock and John Horgan, "Towards a Guide for Constructing and

Disseminating Counter-Narratives to Reduce Support for Terrorism," Studies in Conflict \& Terrorism 39, no. 5 (2015): 381-404, 397, https://doi.org/10.1080/1057610X.2015.1116277.

42 Jan-Jaap van Eerten, Bertjan Doosje, Elly Konijn, Beatrice de Graaf and Marielle de Goede, "Developing a Social Media Response to Radicalization," University of Amsterdam, September 2017, https://www.wodc.nl/binaries/2607_Summary_tcm28286137.pdf; Christian Leuprecht, Todd Hataley, Sophia Moskalenko and Clark Mccauley, "Containing the Narrative: Strategy and Tactics in Countering the Storyline of Global Jihad," Journal of Policing, Intelligence and Counter Terrorism 5, no.1 (2010): 42-57, https://doi.org/10.1080/18335300.2010.9686940.

43 Rachel Briggs and Sebastian Feve, "Review of Programs to Counter Narratives of Violent Extremism: What Works and What are the Implications for Government?" Institute for Strategic Dialogue, 2013, 6, https://www.counterextremism.org/resources/details/id/444/review-of-programs-tocounter-narratives-of-violentextremism-what-works-and-what-are-the-implications-forgovernment.

44 Briggs and Feve, "Review of Programs,", 6.

45 Steven R. Corman, "Understanding the Role of Narrative in Extremist Strategic Communications,"

http://mappingideas.sdsu.edu/old_Mappingideas/SummerWorkshop/2011/Papers/Cor man_Position.pdf.

46 Alex P. Schmid, "Al-Qaeda's 'Single Narrative' and Attempts to Develop CounterNarratives: The State of Knowledge," https://www.icct.nl/download/file/Schmid-AlQaeda's-Single-Narrative-and-Attempts-to-Develop-Counter-Narratives-January2014.pdf; Rachel Briggs and Sebastian Feve, "Review of Programs to Counter Narratives of Violent Extremism: What Works and What are the Implications for Government?," (2013) Counterestremism.org, https://www.counterextremism.org/resources/details/id/444/review-of-programs-tocounter-narratives-of-violent-extremism-what-works-and-what-are-the-implications-forgovernment.

47 Schmid, "Al-Qaeda's 'Single Narrative'."

${ }^{48}$ Kate Ferguson, "Countering Violent Extremism through Media and Communication Strategies," University of East Anglia, 2016, http://www.paccsresearch.org.uk/wp- 
content/uploads/2016/o3/Countering-Violent-Extremism-Through-Media-andCommunication-Strategies-.pdf.

49 Ann-Sophie Hemmingsen and Karin Ingrid Castro, "The Trouble with CounterNarratives," Danish Institute for International Studies, 2017, 19, http://pure.diis.dk/ws/files/784884/DIIS_RP_2017_1.pdf.

$5^{\circ}$ As cited in Alastair Reed, "An Inconvenient Truth: Countering Terrorist NarrativesFighting a Threat We Do Not Understand," International Centre for Counter-Terrorism, July 2018, https://icct.nl/publication/an-inconvenient-truth-countering-terroristnarratives-fighting-a-threat-we-do-not-understand/.

${ }^{11}$ Paul Bell, "ISIS and Violent Extremism: Is the West's Counter-Narrative Making the Problem Worse?" Influence, June 25, 2015, https://influenceonline.co.uk/2015/o6/25/isis-violent-extremism-wests-counternarrative-making-problem-worse/; Amy E. Kasper, "Counter-Narratives and the 'Backfire Effect,"' Universiteit Leiden, 2017, https://www.leidensafetyandsecurityblog.nl/articles/counter-narratives-and-thebackfire-effect.

${ }^{2}$ Attempts directed at aggressively and directly targeting potential recruits could backfire. It could elicit defiance on the part of recruits and be perceived as an insult. For instance, in the context of an individual who justifies the fight against Syrian president Bashar on humanitarian basis. Infante, D.A., et al. "Initiating and Reciprocating Verbal Aggression: Effects on Credibility and Credited Valid Arguments," Communication Studies 43, no.3 (1993): 182-190, http://dx.doi.org/10.1080/10510979209368370; Anne Speckhard and Ardian Shajkovci, "Breaking the ISIS Brand Counter-Narratives-Part II: Ethical Considerations in Fighting ISIS Online," Vox Pol, March 7, 2018, http://www. voxpol.eu/breaking-the-isisbrand-counter-narratives-part-ii-ethical-considerations-in-fighting-isis-online/. 53 Jonathan Russell and Haras Rafiq, "Countering Islamist Extremist Narratives: A Strategic Briefings,” Quilliam, January 11, 2015, https://www.quilliaminternational.com/countering-islamist-extremist-narratives-astrategic-briefing/.

54 Ibid.

55 Robert Sullivan, "Meet the Head International Troll Slayer at Google," Vogue, February 15, 2017, https://www.vogue.com/article/google-jigsaw-yasmin-green-internet-trollsweb-security.

${ }^{56}$ Atika Shubert and Florence Davey-Attlee, “'Abdullah X: 'Former Extremist's Cartoon Aims to Stop Young Muslims Joining ISIS," CNN, October 7, 2014, http://www.cnn.com/2014/10/o7/world/abdullah-x-cartoon/index.html. 57 Anne Speckhard, Ardian Shajkovci, Claire Wooster and Neima Izadi, "Mounting a Facebook Brand Awareness and Safety Ad campaign to Break the ISIS Brand in Iraq," Perspectives on Terrorism 12, no. 3 (2018): 50-66 ${ }^{8}$ Anne Speckhard, Ardian Shajkovci and Lorand Bodo, "Fighting ISIS on FacebookBreaking the ISIS Brand Counter-Narratives Project," International Center for the Study of Violent Extremism, 2018, http://www.icsve.org/research-reports/fighting-isis-onfacebook-breaking-the-isis-brand-counter-narratives-project/; Anne Speckhard, Ardian Shajkovci and Lorand Bodo, "Fighting ISIS on Facebook-Breaking the ISIS Brand Counter-Narratives Project," VoxPol, June 27, 2018, https://www.voxpol.eu/fightingisis-on-facebook-breaking-the-isis-brand-counter-narratives-project/; Anne Speckhard, Ardian Shajkovci, Lorand Bodo, and Haris Fazliu," Breaking the ISIS Brand Counter Narratives-Part I: Intervention with Albanian Speaking Facebook Accounts," VoxPol, February 28, 2018, http://www.voxpol.eu/breaking-isis-brand-counter-narrativesintervention-albanian-speaking-facebook-accounts-part-1/.

59 Adam Edelman, "State Department's 'Embarrassing' 'Think Again Turn Away' Twitter Campaign Could Actually Legitimize Terrorists: Expert," New York Daily News, September 16, 2014, https://www.nydailynews.com/news/politics/state-departmentembarrassing-turn-twitter-campaign-legitimizes-terrorists-expert-article-1.1941990\# . 60 Anne Speckhard, Bride of ISIS: One Young Woman's Journey into Homegrown Terrorism (McLean: Advances Press, 2015). 
${ }^{61}$ Anne Speckhard, "The Lethal Cocktail of Terrorism," International Center for the Study of Violent Extremism," 2016, http://www.icsve.org/brief-reports/the-lethalcocktail-of-terrorism/; Anne Speckhard, Ardian Shajkovci, Ahmet S. Yayla, "Following a Military Defeat of ISIS in Syria and Iraq: What Happens Next After the Military Victory and the Return of Foreign Fighters," Journal of Terrorism Research 8, no.1 (2017): 8189, http://dx.doi.org/10.15664/jtr.1341; Anne Speckhard and Ahmet S. Yayla, “ Eyewitness Accounts from Recent Defectors from Islamic State: Why they Joined, What they say, Why they Quit?” Perspectives on Terrorism 9, no. 6 (2015): 95-117, http://www.terrorismanalysts.com/pt/index.php/pot/article/view/475/html. 62 Author discussions with CVE professionals in Europe (Prevent Counselors in UK). ICSVE research: Allison McDowell Smith, Anne Speckhard, and Ahmet S. Yayla, "Beating ISIS in the Digital Space: Focus Testing ISIS Defector Counter Narrative Videos with American College Students," Journal for Deradicalization, no 10 (2017): 50-76, http://journals.sfu.ca/jd/index.php/jd/article/view/83; Anne Speckhard and Ardian Shajkovci, "Fighting ISIS in the Digital Space in Jordan," Modern Diplomacy, October 29, 2018, https://moderndiplomacy.eu/2018/10/29/fighting-isis-in-the-digital-space-injordan/. ICSVE studies: Anne Speckhard and Ardian Shajkovci, "Confronting an ISIS Emir: ICSVE's Breaking the ISIS Brand Counter-Narrative Videos,” CTX 8, no.1 (2018): 5-14, https://www.researchgate.net/publication/325119336_Confronting_an_ISIS_Emir_ICS VE's_Breaking_the_ISIS_Brand_Counter_Narratives_Project_Videos; Anne Speckhard, Ardian Shajkovci, Claire Wooster and Neima Izadi. "Mounting a Facebook Brand Awareness and Safety Ad campaign to Break the ISIS Brand in Iraq," Perspectives on Terrorism 12 no. 3, (2018), https://www.universiteitleiden.nl/binaries/content/assets/customsites/perspectives-onterrorism/2018/issue-3/o4---mounting-a-facebook-brand-awareness-and-safety-adcampaign-to-break-the-isis-brand-in-ira.pdf; Speckhard, Mc-Dowell Smith and Yayla "Beating ISIS in the Digital Space: Anne Speckhard, Ardian Shajkovci, Claire Wooster and Neima Izadi, "Engaging English Speaking Facebook Users in an Anti-ISIS Awareness Campaign," Journal of Strategic Security 11, no. 3 (2018): 52-78, https://doi.org/10.5038/1944-0472.11.3.1679.

63 Jan-Jaap van Eerten, Bertjan Doosje, Elly Konijn, Beatrice de Graaf and Marielle de Goede, "Developing a Social Media Response to Radicalization," (2017), https://dspace.library.uu.nl/handle/1874/360002.

64 Anne Speckhard, Ardian Shajkovci, and Lorand Bodo, "Fighting ISIS on FacebookBreaking the ISIS Brand Counter-Narratives Project;" Anne Speckhard, Ardian Shajkovci, Lorand Bodo, and Haris Fazliu,” Breaking the ISIS Brand Counter -Narratives-Part I: Intervention with Albanian Speaking Facebook Accounts.”

65 Kristina Davis, "Former San Diego Cleric a Prolific Terror Recruiter," The San Diego Union-Tribune, October 2, 2016, http://www.sandiegouniontribune.com/sd-me-awlakiterrorism-20160929-story.html.

${ }^{66}$ Holly Yan, Sonia Moghe, and Greg Botelho, "Douglas McArthur McCain: From American Kid to Jihadi in Syria," CNN, September 3, 2014, https://www.cnn.com/2014/o8/27/us/who-was-douglas-mccain/index.html. 67 Department of Justice, "Somali Immigrant Sentenced for Providing Support to Foreign Terrorists," 2014, https://www.justice.gov/usao-sdca/pr/somali-immigrant-sentenced-providing-supportforeign-terrorists.

${ }^{68}$ Note: While table reflects 5 participants in each focus group, some participants chose not to disclose their personal data.

${ }^{69}$ Icek Ajzen and Martin Fishbein, "The Influence of Attitudes on Behavior,"

ResearchGate, 2005,

https://www.researchgate.net/publication/264000974_The_Influence_of_Attitudes_on Behavior.

${ }^{70}$ Hussein Tahiri, "Community and Radicalisation: An Examination of Perceptions, Ideas, Beliefs and Solutions Throughout Australia," Victoria University, September 2013, https://www.vu.edu.au/sites/default/files/ccdw/pdfs/community-and- 
radicalisation.pdf; Freedom C. Onuoha, "Why do Youth Join Boko Haram," United States Institute of Peace, 2014, https://www.usip.org/sites/default/files/SR348Why_do_Youth_Join_Boko_Haram.pdf; Fahid Qurashi, "The Prevent Strategy and the UK 'War on Terror;' Embedding Infrastructures of Surveillance in Muslim Communities," Palgrave Communications 4, no. 1 (2018): 1-13, https://www.nature.com/articles/s41599-017-0061-9\#Sec14; Richard A. Krueger, Focus Groups: A Practical Guide for Applied Research. 5th ed. (Thousand Oaks: Sage Publications, Inc, 2015).

${ }^{71}$ Ivana Acocella, " The Focus Groups in Social Research : Advantages and Disadvantages , "International Journal of Methodology 46, no. 4 (2012): 1125-1136; Michael X. Delli Carpini, "The Method is the Message; Focus Groups as a Method of Social, Psychological, and Political Inquiry, University of Pennsylvania Scholarly Commons,1994, https://pdfs.semanticscholar.org/a3b4/8ffb3d1a4651884b7ed2261feaee45644ef6.pdf. ${ }^{72}$ Irving L. Janis, "The Problem of Validating Content Analysis," in Language of Politics: Studies in Quantitative Semantics, eds. Harold D. Lasswell and Nathan Leites, (Cambridge: MIT, 1949), 55-82.

73 Stewart, https://www.sagepub.com/sites/default/files/upmbinaries/11007_Chapter_7.pdf 74 John W. Creswell, Qualitative Inquiry and Research Design: Choosing among Five Approaches. $3^{\text {rd }}$ ed. (Thousand Oaks: Sage Publications, Inc., 2013), 195.

$75 \mathrm{Kappa}, k=\frac{p_{0}-p_{e}}{1-p_{e}}$. The calculated Kappa of .70 denotes a moderate inter-rater agreement.

${ }^{76}$ John W. Creswell, Qualitative Inquiry and Research Design: Choosing among Five Approaches, 193.

77 Valerie J. Janesick, "Stretching” Exercises for Qualitative Researchers, $3^{\text {rd }}$ ed (Thousand Oaks, CA: Sage Publication, Inc., 2011).

78 Julia T. Wood, "Gendered Media: The Influence of Media on Views of Gender," University of North Carolina at Chapel, n.d., https://www.nyu.edu/classes/jackson/causes.of.gender.inequality/Readings/Wood\%20\%20Gendered\%20Media\%20-\%2094.pdf.

79 Denotes the number of participants who agreed with respective statements. For instance, the first row reflects that 3 individuals indicated 7 , one indicated 5 , and one indicated 4 on a scale from 1-7 (7-highest/1-lowest agreement).

${ }^{80}$ Note that most participants expressed unfavorable views towards ISIS. In addition, most, if not all, did not appear radical in their views. That said, one cannot also discount the fact that participants might have refrained, for a variety of reasons, from expressing and discussing their real (extremist) views.

${ }^{81}$ Anne Speckhard and Ardian Shajkovci, "Focus-Testing ISIS Defector CounterNarrative Videos in Jordan," [Manuscript in progress].

82 Terrorism Act 2006, https://www.nyu.edu/classes/jackson/causes.of.gender.inequality/Readings/Wood\%20\%20Gendered\%20Media\%20-\%2094.pdf

83 Anne Speckhard, Ardian Shajkovci, Ahmet S. Yayla, Following a Military Defeat of ISIS in Syria and Iraq: What Happens Next After the Military Victory and the Return of Foreign Fighters."

84 Normally, our large-scale focus group interventions include pre-tests, which are given out prior to testing the videos. In this case, the moderator omitted their use, and we only came to know about the participants' pre-existing views on ISIS from the discussion comments. There is a caveat to the use of pre-test/post-test model, which we also try to avoid. For instance, changes in attitude measured in a short pre-term and post-testing situation may not translate into actual behavioral change or endure over time. In addition, often, as we have come to learn in our line of research, pre-test measurements can, in fact, sensitize individuals to the issues we are trying to address, which makes it difficult to discern if our treatment had any effect or not. To demonstrate, if we attempt to measure a group's view on ISIS-related violence after first exposing it to ISIS violence, the 
pre-test measurements that we utilize to ask questions about ISIS violence may stimulate some within the group to seek information about ISIS on their own. In this regard, the question becomes: What factors caused the change in the individuals studied? Is it the pretest or our treatment? While pre-test/post designs are important, it is our view that one most carefully weigh in if pre-tests would add any value to the study, and if so, under what circumstances. Pre-testing in a group of individuals who already feel they are under state scrutiny and are for that reason unlikely to admit they support ISIS can prove unfruitful. Having said that, ICSVE researchers also recognize methodological strengths of pre-testing and continue to seek more creative ways to pre-test in their future interventions.

85 The use of counter narratives in the realm of CVE remains a highly debated issue. Anne Speckhard and Ardian Shajkovci, "Perspective: Challenges in Creating, Deploying Counter-Narratives to Deter Would-be Terrorists," Homeland Security Today, November 27, 2018, https://www.hstoday.us/subject-matter-areas/terrorism-study/perspectivechallenges-in-creating-deploying-counter-narratives-to-deter-would-be-terrorists/. ${ }^{86}$ For example research guidelines and effective methods to studying violent extremism within vulnerable communities, including Somali-American community in the United States, file://C:/Users/ardian/Downloads/Methods\%2oBrief.pdf

${ }^{87}$ Speckhard, Shajkovci, and Bodo, "Fighting ISIS on Facebook;" Speckhard, Shajkovci, Bodo, and Fazliu," Breaking the ISIS Brand Counter -Narratives-Part I." ${ }^{88}$ Fares Braizat, Anne Speckhard, Ardian Shajkovci, and Amer Sabaileh, "Determining Youth Radicalization in Jordan," International Center for the Study of Violent Extremism, 2017, http://www.icsve.org/research-reports/determining-youthradicalization-in-jordan/; Anne Speckhard and Ardian Shajkovci, "Focus-Testing ISIS Defector Counter-Narrative Videos in Jordan. [Manuscript in progress]. 


\section{Appendix A}

\section{Breaking the ISIS Brand Counter-Narrative Project}

The International Center for the Study of Violent Extremism (ICSVE) researchers, alongside its European branch staff members in Brussels, Belgium, has been interviewing ISIS defectors, returnees, and prisoners over the last three years-most interviews captured on video with a sample of 94 interviews having been collected worldwide to date. ICSVE researchers have also interviewed 16 al-Shabaab members and their family members. The resulting video interviews are edited down to their most damning content to discredit ISIS (and organizations like ISIS) and delegitimize them as corrupt, un-Islamic, and brutal. The video clips feature ISIS insiders denouncing the group as well as make use of actual ISIS propaganda film (reframed with disgust and turned back against itself) to illustrate the speaker's words. These counter narrative videos depict mostly young men and women who were drawn into ISIS out of hopes for a better life, a desire to live an Islamic way of life, and to build the Islamic Caliphate. They were drawn out of vulnerabilities that often match those in the Somali American community. The ICSVE-produced narratives feature how the speaker was drawn into the group, what he/she at first believed and liked, and how he/she was deeply disappointed over time. The speakers discuss and share the experiences that turned them away from ISIS and the price they paid, in many cases, for joining. They also advise others not to join.

The video clips are subtitled in the over 21 languages in which ISIS recruits (Albanian, Arabic, Bosnian, Serbo-Croatian, Finnish, French, German, Italian, Russian, Somali, Spanish, Swedish, Turkish, and UzbekMany of these languages are relevant to migrant and immigrant descent Muslim youth, as well as ordinary citizens that ISIS and organizations like ISIS are reaching inside the United States and elsewhere. Our experience with Somali American youth, however, is that they would generally interact with our English subtitled videos.

The videos are currently being used on five continents by law enforcement, intelligence officers, counselors, teachers, prison workers and other P/CVE professionals. The following represents applications of our counternarrative videos. It also spells out several key indicators that serve as both direct and indirect measure of our success in terms of detection, early intervention, and prevention using these counter narratives:

- A thirteen-year-old boy from London, UK, hell-bent on going to Raqqa, Syria, turned back by viewing one of the ICSVE-produced videos. The account was documented and reported by a UK Prevent counselor who worked closely with the boy.

- An ISIS emir (ISIS superior) interviewed in Iraq by ICSVE researchers hanging his head in shame after viewing two of the 
ICSVE-produced counternarratives, and admitting, "We were wrong. We argued over some of these in the group [as presented in our counternarratives]. We gave a bad face to Islam."

- Multiple focus groups of the ICSVE counter-narratives in the United States, Central Asia, the Middle East (With vulnerable youth in hotbeds of radicalization, such as Zarqa, Irbid, and Salt in Jordan), and the Balkans, leading to open and lively discussions, as well as better understandings on how youth view ISIS and what their vulnerabilities are in potentially being recruited into the group. The focus groups also served to understand what resonates most with ISIS supporters and sympathizers in terms of our content and how the emotionally evocative nature of the videos helped open up countering violent extremism discussions that might otherwise be hard to hold, as the participants might be reticent to share their experiences and concerns. This helped to solidify our belief in the effectiveness of our counter-narrative videos.

- Prison and CVE officials in Central Asia agreeing that most effective narratives against violent extremist group recruitment come from convicted terrorists who engage with fellow prisoners in ideological and religious debates and from ISIS defectors and returnees from the conflict zones in Iraq and Syria who can communicate about the dangers of joining violent extremist groups. Our videos are currently being used by law enforcement officials in Kyrgyzstan (hosted on their official website) to fight and raise awareness about the appeal of violent extremism in the country. Through use of counter-narratives such as ours, they also hope to use them in prison prevention and deradicalization efforts, including in the case of those who have served prison time and are now on probation.

- Training law enforcement, intelligence officers, and other CVE professionals around the world on their use and applications. Working closely with teachers as well. The U.S. Embassy in Copenhagen is making them available in Danish subtitles. The counter narratives are also accompanied with study guides in Danish for teachers to use as a prevention and intervention tools in their respective classrooms.

- Sending out our counter-narratives on Facebook and Telegram in attempts to reach and influence ISIS supporters and sympathizers online. ICSVE researchers successfully identified 5o English and 77 Albanian speaking Facebook profiles that were coded as highly radicalized based on their endorsements of ISIS materials and association with ISIS-related networks online. These accounts were successfully tagged with ICSVE videos in attempts to generate increased cognitive dissonance and discussions against ISIS.

- Conducting over 60 awareness campaigns over Facebook, resulting in over 1.7 million views in Iraq alone. Considerable discussion was generated in these campaigns as well. Such discussions serve as a 
testament to the ability of the ICSVE counter narrative videos to evoke thought-provoking engagement.

- Increasing interaction over YouTube with the ICSVE counter narrative videos, including many claims that ISIS is still strong and powerful. This indicates that our videos are reaching the correct audiences. The ICSVE team has recently built a new website (www.theRealJihad.org) to not only measure the efficacy of its interventions online (for example, tracing conversions, leads, etc.) but also redirect those landing on its website to more tolerant interpretations of Islam and referrals for psychological and other support to walk away from terrorism. We hope that the website will also lead the viewer into a deeper engagement with our counter narrative materials. The English version of the website already has over 90,000 viewers.

- The ICSVE team is also continuing to follow up on the training provided to law enforcement, intelligence, and other CVE practitioners worldwide to generate an assessment on the extent to which such trainings have better equipped these professionals in their fight against violent extremism. 